\section{D) Check for updates}

Cite this: Dalton Trans., 2019, 48 11838

Received 20th June 2019

Accepted 1st July 2019

DOI: $10.1039 / c 9 d t 02614 b$

rsc.li/dalton

\title{
Carbohydrate-functionalized N-heterocyclic carbene Ru(II) complexes: synthesis, characterization and catalytic transfer hydrogenation activity $\dagger$
}

\author{
Joseph P. Byrne, (D) Pauline Musembi and Martin Albrecht (D)*
}

\begin{abstract}
Three Ru complexes containing carbohydrate/N-heterocyclic carbene hybrid ligands were synthesized that were comprised of a triazolylidene coordination site and a directly linked per-acetylated glucosyl (5Glc) or galactosyl unit (5Gal), or a glycosyl unit linked through an ethylene spacer (6). Electrochemical and UV-vis analysis indicate only minor perturbation of the electronic configuration of the metal center upon carbohydrate installation. Deprotection of the carbohydrate was accomplished under basic conditions to afford complexes that were stable in solution over several hours, but decomposed in the solid state. Complexes $\mathbf{5}$ and $\mathbf{6}$ were used as pre-catalysts for transfer hydrogenation of ketones under basic conditions, i.e. conditions that lead to in situ deprotection of the carbohydrate entity. The carbohydrate directly influences the catalytic activity of the metal center. Remotely linked carbohydrates (complex 6) induce significantly lower catalytic activity than directly linked carbohydrates (complexes 5Glc, 5Gal), while unfunctionalized triazolylidenes are an order of magnitude more active. These observations and substrate variations strongly suggest that substrate bonding is rate-limiting for transfer hydrogenation in these hybrid carbohydrate/triazolylidene systems.
\end{abstract}

\section{Introduction}

$\mathrm{N}-\mathrm{Heterocyclic}$ carbenes (NHCs) act as versatile ligands for various catalytic systems, ${ }^{1}$ as well as for biological and materials applications. ${ }^{2}$ Ruthenium complexes of NHCs, in particular, have shown a broad range of catalytic activity, ${ }^{3-6}$ with application in olefin-metathesis, ${ }^{7-9}$ transfer hydrogenation, ${ }^{10-18}$ as well as oxidation of alcohols and amines, ${ }^{19-23}$ and water. ${ }^{24}$ 1,2,3-Triazolylidenes have emerged as a particularly promising subclass of NHC ligands that are stronger $\sigma$-donors than Arduengo-type imidazolylidenes and easily accessible through $\mathrm{Cu}(\mathrm{I})$-catalyzed azide-alkyne cycloaddition (CuAAC) 'click' chemistry. ${ }^{25}$ Because of these characteristics, they have found widespread applications in catalysis. $^{26,27}$ CuAAC chemistry has excellent compatibility with most functional groups due to the mild reaction conditions $^{28,29}$ and consequently triazoles have become ubiquitous linkers for molecular components in various domains

Department of Chemistry and Biochemistry, University of Bern, Freiestrasse 3, 3012 Bern, Switzerland. E-mail: martin.albrecht@dcb.unibe.ch $\dagger$ Electronic supplementary information (ESI) available: Experimental details of carbohydrate azide synthesis; ${ }^{1} \mathrm{H}$ and ${ }^{13} \mathrm{C}$ spectra of new compounds and HSQC spectra of deprotected complex; catalytic data; chiral gas chromatogram of acetophenone transfer hydrogenation product. See DOI: 10.1039/c9dt02614b of (bio)chemistry, including materials science, ${ }^{30-32}$ medicinal $^{33}$ and supramolecular chemistry, ${ }^{34-37}$ as well as peptide/ carbohydrate functionalisation. ${ }^{38-42}$ This CuAAC synthetic methodology allows the introduction of natural chiral pool motifs such as carbohydrates into triazoles, and thereby facilitates the decoration of 1,2,3-triazolylidene NHCs with functional wingtip substituents. ${ }^{26,43-45}$

The introduction of carbohydrate substituents on the triazolylidene scaffold is particularly attractive as this approach introduces functional groups in close proximity to the metal active site. Such cooperation of ligand sites and the metal center has been demonstrated in so-called bifunctional catalysts, as introduced elegantly with Noyori-type catalysts containing an amide functionality, ${ }^{46-48}$ and Shvo's catalyst featuring a proximal oxygen functionality. ${ }^{49,50}$ Bifunctional NHC ligands have shown promise in a range of catalytic transformations including hydrogenations, giving rise to increased catalytic activities when compared to more classical analogs. ${ }^{13,17,23,51-55}$

The use of carbohydrate motifs in homogenous transition metal catalysts has attracted considerable attention, particularly for introducing chirality and water solubility. Several complexes with carbohydrate-based phosphine and phosphinite ligand scaffolds have shown excellent performance in asymmetric catalysis. ${ }^{56-58}$ Similar work with N-heterocyclic carbene 
ligands, however, is much more scarce. ${ }^{59,60}$ In pioneering work, Dyson and co-workers investigated the anticancer activity of $\mathrm{Ru}$ complexes of carbohydrate-functionalized NHC ligands, ${ }^{60,61}$ though only few examples have explored the catalytic activity of such carbohydrate-NHC hybrid complexes. 8,22,62 Imidazolylidene systems functionalized with two carbohydrate wingtip groups, for example, induced up to $60 \%$ ee in asymmetric $\mathrm{Rh}(\mathrm{I})$-catalyzed hydrosilylation of ketones. $^{62}$ We have demonstrated that deprotected carbohydrate substituents in NHC-Ir(III) complexes are beneficial for base-free alcohol and amine oxidation. ${ }^{22}$ Based on these results, we became interested in exploiting this ligand design motif for transfer hydrogenation.

Herein we report three novel $\mathrm{Ru}$-triazolylidene complexes that incorporate carbohydrate functionality, including their photophysical and electrochemical properties as well as their catalytic activity in transfer hydrogenation of ketones, which revealed that complexes are efficiently deprotected in situ under the basic catalytic conditions.

\section{Results and discussion}

\section{Synthesis and characterization}

Triazole precursors $\mathbf{1}$ were synthesized in moderate yields by the CuAAC reaction from 1-hexyne and acetyl-protected anomeric azide derivatives of glucose and galactose (Scheme 1). ${ }^{63}$ HRMS analysis (ESI+) confirmed formation of 1Glc and 1Gal by characteristic signals at $m / z=456.1985$ and 456.1980, respectively $\left(\mathrm{m} / \mathrm{z}=456.1977\right.$ calculated for $\left.[\mathrm{M}+\mathrm{H}]^{+}\right)$. Also, ${ }^{1} \mathrm{H}$ NMR analysis showed the triazolyl $\mathrm{CH}$ resonance for both compounds 1Glc and 1Gal at $7.5 \mathrm{ppm}$. Importantly, only a single anomeric proton resonance was observed for each triazole as a doublet at $\delta_{\mathrm{H}} 5.85$ and 5.81, respectively, each with a coupling constant of $9 \mathrm{~Hz}$, which is consistent with stereoselective formation of $\beta$-anomers of the monosaccharide moiety. The remaining carbohydrate $\mathrm{CH}$ resonances differed between the glucose and galactose derivative, and the acetyl protecting groups appeared as four singlets between 1.7 and $1.3 \mathrm{ppm}$.

Glycosidation of peracetylated glucopyranose with 1-bromoethanol and subsequent $\mathrm{S}_{\mathrm{N}} 2$ reaction with $\mathrm{NaN}_{3}$ according to literature procedures, ${ }^{64,65}$ yielded 1-azidoethyl-2,3,4,6-tetraacetylglucopyranoside, containing an ethylene spacer between the carbohydrate and azide functional groups. CuAAC of this azide with 1-hexyne (Scheme 1) yielded triazole 2, which gave a signal in HRMS analysis at $\mathrm{m} / \mathrm{z}=500.2236$, corresponding to $[\mathrm{M}+\mathrm{H}]^{+}$(calculated $\mathrm{m} / z=500.2239$ ). The triazolyl $\mathrm{CH}$ resonance appeared in the ${ }^{1} \mathrm{H}$ NMR spectrum at $7.21 \mathrm{ppm}$ and the anomeric proton resonance was much less deshielded than in the spectra of 1 , appearing as a doublet at $4.40 \mathrm{ppm}$, which overlaps with a multiplet from the ethylene spacer. The anomeric coupling constant of $7.9 \mathrm{~Hz}$ is again consistent with a $\beta$-conformation.

Carbohydrate-triazole compounds $\mathbf{1}$ and $\mathbf{2}$ were alkylated with Meerwein's reagent and isolated by precipitation from methanol to afford triazolium salts 3 Glc, 3 Gal and 4 in high to quantitative yields. A diagnostic downfield shift of $c a .1 \mathrm{ppm}$ of the triazole $\mathrm{CH}$ resonance was observed upon alkylation $\left(\delta_{\mathrm{H}}=8.56,8.50\right.$ and 8.17 , respectively) along with a new singlet corresponding to the triazolium $N$-methyl group. The anomeric proton resonances also shifted $0.2-0.4 \mathrm{ppm}$ downfield. HRMS analysis revealed $\mathrm{a} \mathrm{M}^{+}$ion $\left[\mathrm{M}-\mathrm{BF}_{4}\right]^{+}$that is 14 amu higher than those of the corresponding triazole precursor $[\mathrm{M}+\mathrm{H}]^{+}$ions, indicative of successful methylation. These salts were used as ligand precursors without further purification.

Ruthenium(II) triazolylidene arene complexes $\mathbf{5}$ and $\mathbf{6}$ were synthesized from these triazolium salts via the wellestablished ${ }^{25,66}$ transmetalation procedure using $\mathrm{Ag}_{2} \mathrm{O}$ and
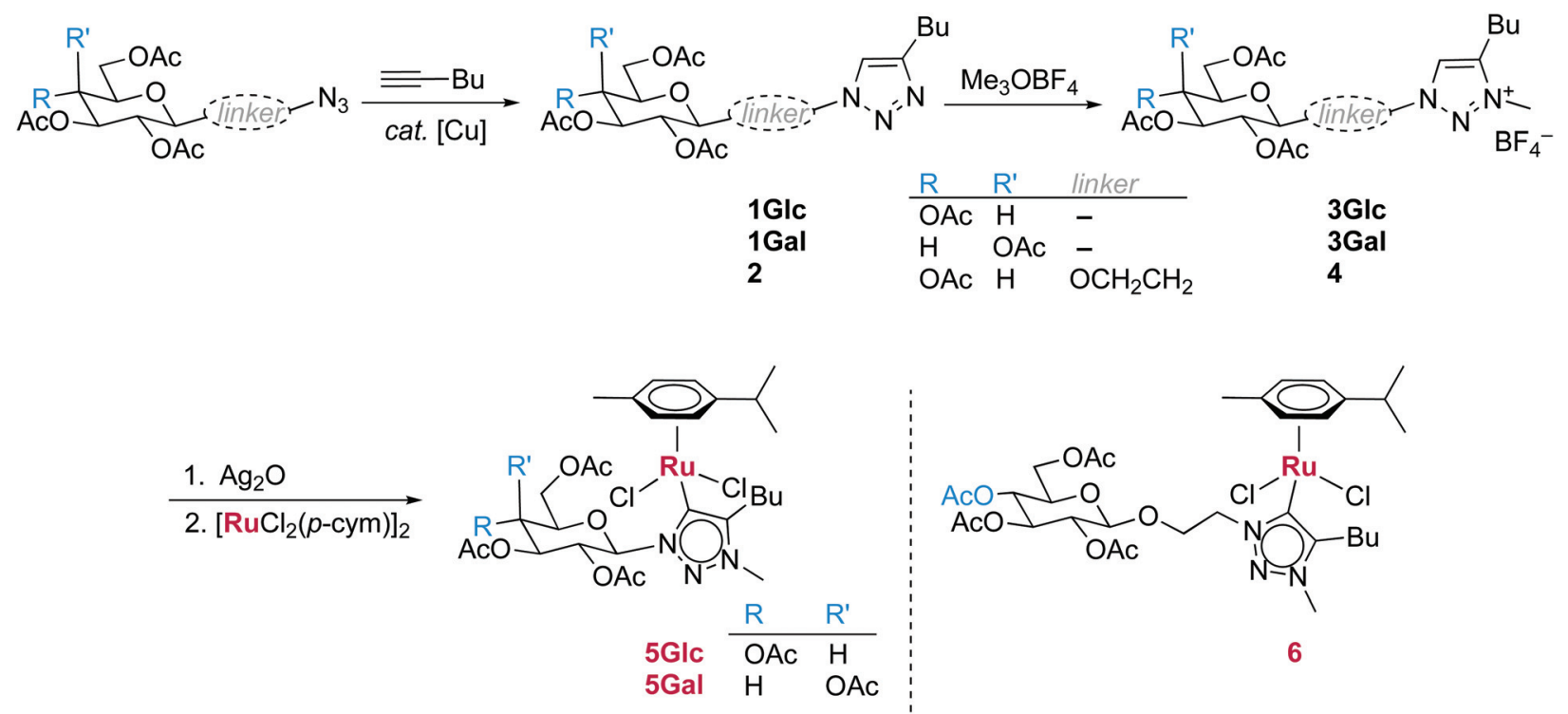

Scheme 1 Synthesis of complexes 5Glc, 5 Gal and 6. 
$\left[\operatorname{RuCl}_{2}(p \text {-cym })\right]_{2}$. The silver(I) carbene intermediate was not isolated, but its formation was monitored by disappearance of the triazolium $\mathrm{CH}$ resonance in the ${ }^{1} \mathrm{H}$ NMR spectrum and by HRMS analysis $\left(m / z=1045.3148\right.$ for $\left.\left[\mathrm{Ag}(3 \mathrm{Glc}-\mathrm{H})_{2}\right]^{+}\right)$. Isolation of the transmetalated ruthenium(II) complexes by flash chromatography provided microanalytically pure complexes 5 in good yields (60-80\%), yet 6 in a only moderate $30 \%$ yield. Successful ruthenation was confirmed by HRMS analysis, showing signals for the $[\mathrm{M}-\mathrm{Cl}]^{+}$ion at $m / z=740.1885$, 740.1886 and 784.2153, for 5Glc, 5Gal and 6, respectively. Complex formation was further supported via NMR analysis by the absence of the downfield ${ }^{1} \mathrm{H}$ resonance, corresponding to a triazolium $\mathrm{CH}$ group in the ligand precursor, and a characteristic $^{14}$ carbenic ${ }^{13} \mathrm{C}$ resonance at $167 \mathrm{ppm}$ (5) or $163 \mathrm{ppm}(6)$. The anomeric proton resonances in the spectra of 5 were further deshielded by 0.5-0.7 ppm when compared to the triazolium precursors and significantly broadened, appearing at $\delta_{\mathrm{H}} 6.76$ and 6.86 for 5Glc and 5Gal, respectively. This downfield shift indicates electronic perturbation at the anomeric position upon complexation when the carbohydrate is directly bound to the 1,2,3-triazolylidene ligand. In contrast, the shift of the anomeric resonance upon ruthenation is negligible for 6, which contains an ethylene spacer between the triazolylidene heterocycle and the carbohydrate unit. Moreover, complex 6 features two doublet resonances in the aromatic region due to the $p$-cymene ligand in the ${ }^{1} \mathrm{H}$ NMR spectrum, suggesting $C_{\mathrm{s}}$ symmetry of the complex. In contrast, the p-cymene ligand is dissymmetric in complexes 5Glc and 5Gal revealing four distinct resonances for the aromatic protons and two non-identical isopropyl $\mathrm{CH}_{3}$ doublets at $c a .1 .3 \mathrm{ppm}$ for each complex. This splitting indicates restricted rotation about the $\mathrm{Ru}-\mathrm{C}_{\mathrm{NHC}}$ bond and hence a more rigid second coordination sphere imparted by the directly linked carbohydrate units.

The photophysical and electrochemical properties of 5Glc, 5Gal and 6 in MeCN solution were probed. UV-vis absorption spectra of both the new carbohydrate-derived complexes 5 show a strong absorption band at $\lambda_{\max }=282 \mathrm{~nm}\left(\varepsilon 5700 \mathrm{M}^{-1} \mathrm{~cm}^{-1}\right)$ as well as a shoulder at $236 \mathrm{~nm}$, both tentatively attributed to ligand-centered $n-\pi^{*}, \pi-\pi^{*}$ transitions (Fig. 1a). In the spectrum of 6 an absorbance band at $\lambda_{\max }=272 \mathrm{~nm}$ ( $\varepsilon 4500 \mathrm{M}^{-1} \mathrm{~cm}^{-1}$ ) was observed. Additionally, all complexes feature a broad and weak charge transfer band between 300 and $500 \mathrm{~nm}$, giving rise to the yellow-orange colour of the complexes.

Electrochemical analysis using cyclic voltammetry showed two oxidations for complex 5Glc, a quasi-reversible and presumably metal-based $\mathrm{Ru}^{2+/ 3+}$ process at $E_{1 / 2}=+0.91 \mathrm{~V} v s$. SCE and an irreversible oxidation at $E_{\mathrm{pa}}=+1.50 \mathrm{~V}$ (Fig. 1b, Table 1). 5Gal and 6 showed very similar behavior with only slight shifts of the oxidation potentials. These redox features are reminiscent to those of the known ${ }^{14,67}$ ruthenium complex $\left[\mathrm{RuCl}_{2}(\mathrm{cym})\left(\mathrm{trz}^{\mathrm{BuBu}}\right)\right] 7$ containing two $n$-butyl wingtip groups as triazolylidene substituents $\left(E_{1 / 2}=0.91 \mathrm{~V}, E_{\mathrm{pa}}=1.4 \mathrm{~V} v s\right.$. SCE), indicating that the carbohydrate unit has no significant influence on the electron density at the ruthenium center, and that this unit is not redox active at these potentials.

\section{In situ deprotection of 5Glc}

Deprotection of the carbohydrate unit in complexes 5 and $\mathbf{6}$ is essential for exploiting the potential of the carbohydrate

Table 1 UV-Vis spectroscopic, and electrochemical properties of complexes $5 \mathrm{Glc}, 5 \mathrm{Gal}, 6$ and $7^{a}$

\begin{tabular}{llll}
\hline Complex & $\lambda_{\max }(\mathrm{nm})\left[\varepsilon\left(\mathrm{M}^{-1} \mathrm{~cm}^{-1}\right)\right]$ & $E_{1 / 2}(\mathrm{~V})\left[\Delta E_{\mathrm{p}}(\mathrm{mV})\right]^{b}$ & $E_{\mathrm{pa}}{ }^{c}(\mathrm{~V})$ \\
\hline 5Glc & $282[5700], 236(\mathrm{sh})[10000]$ & $0.91[89]$ & 1.50 \\
5Gal & $282[5700], 236(\mathrm{sh})[13000]$ & $0.96[68]$ & 1.52 \\
$\mathbf{6}$ & $272[4500]$ & $0.92[226]$ & 1.45 \\
7 & $272[4000]$ & $0.91[178]$ & 1.44
\end{tabular}

${ }^{a}$ All measurements in MeCN, sh $=$ shoulder. ${ }^{b}$ All potentials vs. SCE using $\mathrm{Fc}^{+} / \mathrm{Fc}$ as the internal standard $\left(E_{1 / 2}=+0.40 \mathrm{~V}, \Delta E_{\mathrm{p}}=72 \mathrm{mV}\right)$, scan rate $100 \mathrm{mV} \mathrm{s}{ }^{-1},\left[\mathrm{NBu}_{4}\right] \mathrm{PF}_{6}$ as the supporting electrolyte $(0.1 \mathrm{mM}) .{ }^{c}$ Peak potential of irreversible oxidation.
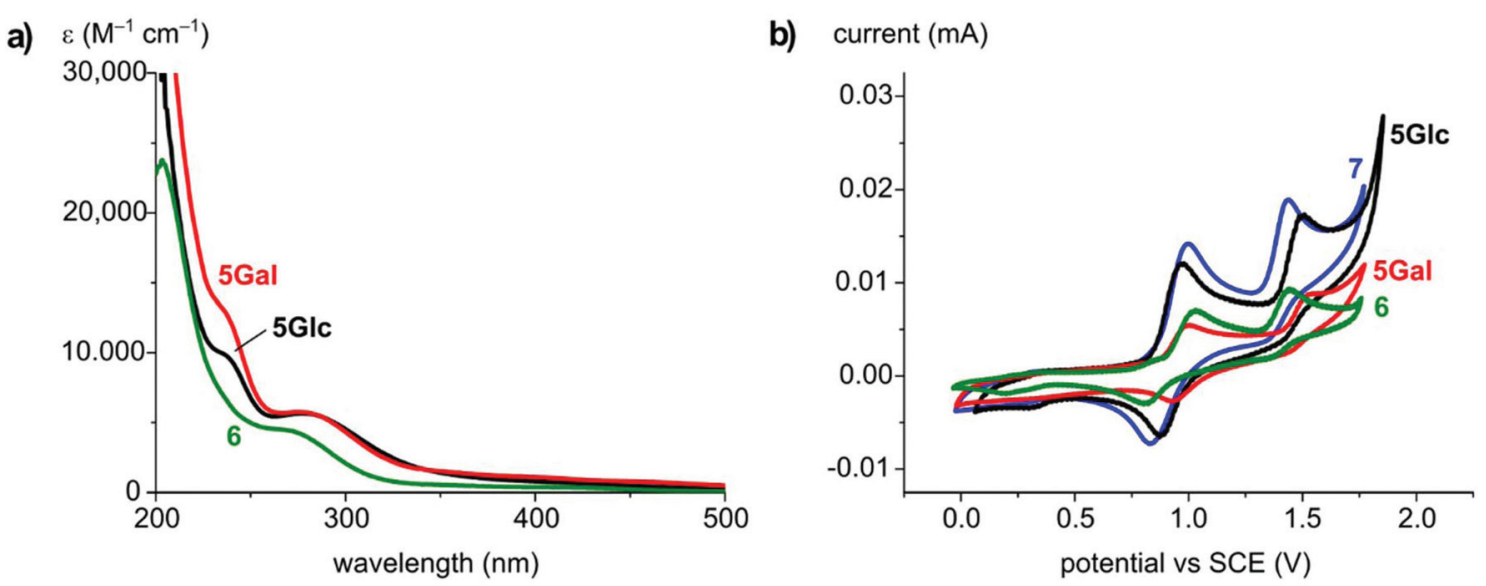

Fig. 1 (a) UV-Vis absorption spectra of $5 \mathrm{Glc}, 5 \mathrm{Gal}$ and 6 at room temperature in MeCN; and (b) cyclic voltammetry of 5Glc, 5Gal, 6, and 7 in MeCN solution, scan rate $100 \mathrm{mV} \mathrm{s}^{-1}$, [NBu 4$] \mathrm{PF}_{6}$ as the supporting electrolyte $(0.1 \mathrm{mM})$, complexes at $0.5 \mathrm{mM}$ except $5 \mathrm{Gal}(0.25 \mathrm{mM})$. 
wingtip group for reductive catalytic processes and for promoting potentially bifunctional interactions involving the carbohydrate hydroxyl groups and the metal center. Such deprotection has been achieved only in a few specific cases. $^{59,68,69}$ Recent results from our laboratory have demonstrated the deacetylation of carbohydrate wingtip groups of iridium complexes in methanolic $\mathrm{HCl}^{22}$ The ruthenium complexes 5 and 6, however, were not stable under these conditions and although deprotection was observed, simultaneous formation of significant amounts of free triazolium salt due to metal dissociation occurred. Acid-lability of Ru-triazolylidene bonds has been established by Grubbs, Bertrand, and coworkers in olefin methathesis catalysis. ${ }^{7}$ The $\mathrm{Ru}$ triazolylidene complexes were also not stable to conventional Zemplén deprotection conditions using methanolic NaOMe. ${ }^{70}$ However, stability tests of complex 5Glc under typical transfer hydrogenation conditions, i.e. $\mathrm{KOH}$ in $\mathrm{PrOH}(20 \mathrm{mM})$ revealed rapid deprotection, which was accompanied by a color change of the reaction solution from orange to yellow (Scheme 2). Deprotection and formation of 8Glc was also accomplished in $\mathrm{D}_{2} \mathrm{O}$ using 10 equiv. $\mathrm{KOH}$ and was confirmed by a HRMS $(\mathrm{ESI}+)$ signal at $m / z=536.1684$, corresponding to $[\mathrm{M}-2 \mathrm{Cl}-\mathrm{H}]^{+}$. Moreover, ${ }^{1} \mathrm{H}$ NMR analysis in $\mathrm{D}_{2} \mathrm{O}$ showed the coalescence of the four distinct acetate signals of 5Glc into a single resonance consistent with the formation of KOAc (see ESI, Fig. S19†). In addition, the $\mathrm{C}^{1}-\mathrm{C}^{5}$ carbohydrate ring proton resonances are shifted upfield upon deprotection. The asymmetry of the $p$-cymene ligand is retained, as indicated by two distinct isopropyl methyl signals at 1.13 and 1.29 ppm. Analogous results were observed for 5Gal, suggesting wider applicability of this method.

The deprotected complex 8Glc was not isolated as a pure solid since it displayed instability over the course of several hours upon drying. In addition, substantial amounts of degradation products were detected by ${ }^{1} \mathrm{H}$ NMR spectroscopy over the course of $24 \mathrm{~h}$ when kept in either $\mathrm{D}_{2} \mathrm{O}$ or $\left(\mathrm{CD}_{3}\right)_{2} \mathrm{CDOD}$ solution. Consequently, the more robust protected complexes $\mathbf{5}$ were used as pre-catalysts and complexes $\mathbf{8}$ were generated by in situ deprotection in the course of transfer hydrogenation catalysis.

\section{Transfer hydrogenation catalysis}

To assess the suitability of the carbohydrate-functionalized carbene ruthenium complexes as pre-catalysts for base-promoted transfer hydrogenation of ketones, a model reaction with benzophenone was carried out under standard con-

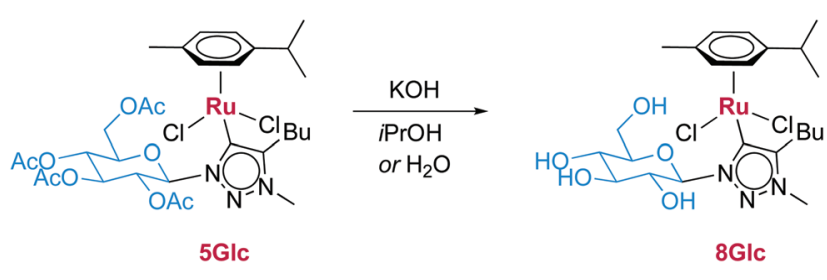

Scheme 2 Synthesis of $8 \mathrm{Glc}$ by base-mediated deprotection of 5Glc. ditions, ${ }^{43}$ i.e., refluxing iPrOH as hydrogen source, $\mathrm{KOH}$ as activator, 100:10:1 substrate/base/complex ratio. For both 8Glc and 8Gal, both generated in situ from the acetate-protected precursors $\mathbf{5 G l c}$ and $\mathbf{5 G a l}$, respectively, the reaction proceeded to completion within $8 \mathrm{~h}$, forming diphenylmethanol as the exclusive product (Table 2, entries 1 and 2). The results for both glucose- and galactose-derivatives were essentially identical, suggesting little influence of the remote carbohydrate $\mathrm{C} 4$ configuration and hence no relevance of a chair conformation of the pyranose ring. ${ }^{71}$ Complex 6 featuring an ethylene spacer between the triazolylidene and carbohydrate units showed decreased activity as pre-catalyst for the model reaction, when compared to those complexes with the carbohydrate directly linked to the triazolylidene, reaching only $57 \%$ within $8 \mathrm{~h}$ and incomplete conversion even after $24 \mathrm{~h}$ (84\%, entry 3). In contrast, the unfunctionalized complex 7 generates a considerably faster catalyst and reaches completion in less than $2 \mathrm{~h}\left(\mathrm{TOF}_{50}=310 \mathrm{~h}^{-1}\right)$. These differences point to a direct catalytic relevance of the carbohydrate functionality, either through chelation or through stabilization of substrates or intermediates within the catalytic cycle. The location of the carbohydrate is critical and proximal oxo functionalities are less inhibiting than the more remote functional group in complex 6.

Transfer hydrogenation of benzophenone by 5Glc was not impeded by elemental mercury. Thus, addition of $\mathrm{Hg}(0.2 \mathrm{~g}$, ca. $1 \mathrm{mmol}, 100$ molequiv relative to $\mathrm{Ru}$ ) after $2 \mathrm{~h}$ when the reaction has reached $34 \%$ substrate conversion proceeded to full conversion (entry 5). The initial decrease of activity was attributed to mass transfer limitations induced by the mercury drop. The preservation of catalytic activity supports a homogeneous catalyst as active species rather than significant dissociation of the triazolylidene ligand and formation of a heterogeneous layer as catalytically active phase.

Since the triazolylidene ligand is robustly coordinated to the ruthenium center, transfer hydrogenation allows for evaluating the asymmetric induction of the stereochemically welldefined carbohydrate functionality by using prochiral ketones. Similar carbohydrate-based ligands have previously been shown to be effective in asymmetric catalysis, ${ }^{58,62,72-75}$ including hydrosilylation of ketones. ${ }^{62}$ The enantioselectivity of 5Glc was probed with acetophenone as prochiral substrate for transfer hydrogenation (entry 6). The reaction proceeded at a lower rate than with benzophenone $\left(\mathrm{TOF}_{50}=10\right.$ vs. $\left.20 \mathrm{~h}^{-1}\right)$, reaching $66 \%$ conversion after $8 \mathrm{~h}$ and full conversion after $24 \mathrm{~h}$. Product analysis by chiral gas chromatography revealed negligible enantioselectivity ( $<2 \%$, see ESI, Fig. S28†), indicating that chiral information from the carbohydrate wingtip group is not transferred to the substrate under these conditions. Modification of the chiral pocket and enhanced enantioselectivity may be induced through variation of the carbohydrate, drawing on the vast pool of pyranose and ribose structures present in nature.

In order to investigate electronic and steric influences on substrate reactivity as well as functional group tolerance, a small substrate scope was carried out with derivatives of 
Table 2 Catalytic activity of Ru complexes for transfer hydrogenation of various carbonyl substrates ${ }^{a}$

\begin{tabular}{|c|c|c|c|c|c|c|}
\hline \multirow[b]{3}{*}{ Entry } & \multirow[b]{3}{*}{ Complex } & \multirow[b]{3}{*}{ Substrate } & \multirow{2}{*}{\multicolumn{2}{|c|}{$\frac{\underset{\text { reflux }}{\stackrel{10 \mathrm{~mol} \% \mathrm{cat}}{\mathrm{10H}}} \operatorname{Conversion}^{b}(\%)}{\operatorname{Ar}_{\mathrm{R}}}$}} & \multirow[b]{3}{*}{$\operatorname{TOF}_{50}^{c}\left(\mathrm{~h}^{-1}\right)$} & \multirow[b]{3}{*}{$\sigma_{\mathrm{p}}^{d}$} \\
\hline & & & & & & \\
\hline & & & $8 \mathrm{~h}$ & $24 \mathrm{~h}$ & & \\
\hline 1 & 5Glc & & 98 & $>98$ & 20 & 0 \\
\hline 2 & 5Gal & & $>98$ & $>98$ & 22 & 0 \\
\hline 3 & 6 & & 57 & 84 & 9 & 0 \\
\hline 4 & 7 & & $>98$ & $>98$ & 310 & 0 \\
\hline 5 & $5 \mathbf{G l c}^{e}$ & & 62 & $>98$ & 8 & 0 \\
\hline 6 & 5Glc & & 66 & 98 & 10 & 0 \\
\hline 7 & 5Glc & & 74 & 98 & 13 & - \\
\hline 8 & 5Glc & & 56 & 75 & 8 & +0.23 \\
\hline 9 & 5Glc & & 51 & 77 & 7 & -0.27 \\
\hline 10 & 5Glc & & 62 & 74 & 11 & +0.23 \\
\hline 11 & 5Glc & & 10 & 16 & - & -0.36 \\
\hline 12 & 5Glc & & 15 & 31 & - & -0.66 \\
\hline 13 & 5Glc & & 97 & $>98$ & 60 & - \\
\hline
\end{tabular}

${ }^{a}$ General reaction conditions: Ru complex $(0.01 \mathrm{mmol})$, substrate $(1.0 \mathrm{mmol}), \mathrm{KOH}(0.05 \mathrm{~mL}, 2 \mathrm{M}, 0.1 \mathrm{mmol}), 2$-propanol $(5 \mathrm{~mL})$ at reflux.

${ }^{b}$ Determined by ${ }^{1} \mathrm{H}$ NMR analysis. ${ }^{c} \mathrm{TOF}_{50}$ (mol product)/(mol pre-catalyst) at $50 \%$ conversion. ${ }^{d}$ Hammett parameter of aryl para-substituent.

${ }^{e}$ Elemental $\mathrm{Hg}(c a .1 \mathrm{mmol})$ added after $2 \mathrm{~h}$.

benzophenone and acetophenone using 5Glc as pre-catalyst (entries 7-13). Using sterically more demanding 2-methylacetophenone as substrate in place of acetophenone led to a modest increase in activity $\left(\mathrm{TOF}_{50}=13\right.$, entry 7$)$. Very little variation of activity was noted when using electronically distinct substrates. For example, conversion of electron-withdrawing 4-bromoacetophenone $\left(\sigma_{\mathrm{p}}=+0.23, \mathrm{TOF}_{50}=8 \mathrm{~h}^{-1}\right)$ and electrondonating 4-methoxyacetophenone $\left(\sigma_{\mathrm{p}}=-0.27, \mathrm{TOF}_{50}=7 \mathrm{~h}^{-1}\right)$ was essentially identical (entries 8 and 9). Notably, neither substrate achieved full conversion after $24 \mathrm{~h}$ and thus proved less suitable than unsubstituted acetophenone. 4-Bromobenzophenone showed similar activity $\left(\mathrm{TOF}_{50}=11\right.$, entry 10), implying a markedly decreased performance with respect to the unsubstituted benzophenone. Under the same conditions, benzaldehyde was not converted to the corresponding alcohol. Alcohol and amine substituents markedly inhibited catalytic activity and ketones with these functional groups reached conversions of only 10 and $15 \%$, respectively after $8 \mathrm{~h}$ (entries 11 and 12). In contrast, di(2-pyridyl)ketone was converted much faster than benzophenone $\left(\mathrm{TOF}_{50}=60 \mathrm{vs}\right.$. $20 \mathrm{~h}^{-1}$, entry 13). This substrate scan suggests a few features of the catalytic transfer hydrogenation induced by 8 Glc. First, the lack of influence of electronic substituent effects on the turnover frequency indicates that the rate-limiting step is not associated with substrate conversion. Moreover, the decrease of the rate for the conversion of substituted substrates, in particular in para position, hints to a steric bias and the requirement of sufficient space around the metal center for turnover to proceed. This observation renders $\beta$-hydrogen elimination from coordinated isopropoxide unlikely as rate-limiting step, as this step would be substrate-independent and lead to equal rates. Instead, these data suggest instead that substrate coordination is rate-limiting, a step that is obviously affected by the steric demand and the potential (hydrogen bond) interactions of the carbohydrate with the substrate. Substrate coordination may also involve decoordination of potentially chelating carbo- 
hydrate hydroxy groups from the ruthenium center. This decoordination is accelerated with soft pyridyl coordinating groups (entry 13), which may rationalize the enhanced conversion rate observed with this substrate. In contrast, phenol and aniline functional groups are presumably too acidic and deprotonated under the basic reaction conditions, leading to a strongly coordinating ligand which is even more difficult to be displaced by the carbonyl group for catalytic turnover (entries 11 and 12).

\section{Conclusions}

We have successfully synthesized and characterized new carbohydrate-NHC Ru complexes. Deprotection of acetylated carbohydrate unit on the ruthenium complex was achieved in situ under basic conditions in protic solvents without affecting the $\mathrm{Ru}$-triazolylidene bond and affording the first example of an unprotected carbohydrate-NHC system with $\mathrm{Ru}$. This method provides access to hydroxy-functionalized carbene complexes, even though their isolation is compromised by stability issues. The carbohydrate functionality has a profound impact on catalytic activity in transfer hydrogenation of ketones. Directly triazolylidene-bound glucose substantially enhances turnover rates compared to more remote carbohydrate functionalization, though it reduces activity compared to unfunctionalized carbene complexes. This prominent role of the carbohydrate substituent provides opportunities for further catalyst engineering towards other transformations involving hydrogen transfer such as oxidations or hydrogen borrowing processes, as well as by modulation of the carbohydrate entity using other pyranoses or furanoses to exploit their beneficial properties in catalysis.

\section{Experimental section}

\section{General}

Unless otherwise stated, all reagents were obtained from commercial suppliers and used as received. Carbohydrate azide precursors were prepared according to modified literature procedures. ${ }^{63-65} \mathrm{Ag}_{2} \mathrm{O}$ was used after regeneration by heating to $>160^{\circ} \mathrm{C}$ under vacuum. Dry, degassed solvents were obtained by filtration over columns of dried aluminium oxide under a positive pressure of argon. NMR spectra were recorded on Bruker spectrometer operating at room temperature. Chemical shifts ( $\delta$ in ppm, $J$ in $\mathrm{Hz}$ ) were referenced to residual solvent resonances and are reported downfield from $\mathrm{SiMe}_{4}$. High resolution mass spectrometry and elemental analysis were performed by the Analytical Research Services at University of Bern.

\section{General synthesis of triazoles}

Acetylated pyranosyl azide (1.000 g, $2.68 \mathrm{mmol})$ and 1-hexyne $(0.31 \mathrm{~mL}, 2.7 \mathrm{mmol})$ were reacted in the presence of $\mathrm{CuSO}_{4} \cdot 5 \mathrm{H}_{2} \mathrm{O}(0.270 \mathrm{~g}, 1.07)$ and sodium ascorbate $(0.530 \mathrm{~g}$, $2.68 \mathrm{mmol})$ in tert-butanol-water mixture $(1: 1,20 \mathrm{~mL})$, at room temperature for 3 days. The reaction mixture was diluted with EDTA (20 mL, 0.2 $\mathrm{M}$ in $1.0 \mathrm{M} \mathrm{NH}_{4} \mathrm{OH}_{(\mathrm{aq})}$ solution) and extracted into $\mathrm{CH}_{2} \mathrm{Cl}_{2}(3 \times 20 \mathrm{~mL})$. The organic layers were combined, washed with brine, dried over $\mathrm{MgSO}_{4}$ and filtered through Celite, yielding a white solid (1) or yellow oil (2).

1-(2,3,4,6-Tetra-O-acetyl- $\beta$-D-glucopyranosyl)-4-butyl-1,2,3-triazole (1Glc). Yield: $0.512 \mathrm{~g},(42 \%)$. Anal. calcd for $\mathrm{C}_{20} \mathrm{H}_{29} \mathrm{~N}_{3} \mathrm{O}_{9}$ (455.464 $\mathrm{g} \mathrm{mol}^{-1}$ ): C 52.74, $\mathrm{H} 6.42, \mathrm{~N} \mathrm{9.23 \% ;} \mathrm{found} \mathrm{C} 53.09, \mathrm{H}$ 6.03, N 8.86\%. HRMS (m/z) (ESI+): Calculated for $\mathrm{C}_{20} \mathrm{H}_{30} \mathrm{O}_{9} \mathrm{~N}_{3}{ }^{+}$ $[\mathrm{M}+\mathrm{H}]^{+} m / z=456.1977$; found $m / z=456.1985 .{ }^{1} \mathrm{H} \mathrm{NMR}$ $\left(\mathrm{CDCl}_{3}, 400 \mathrm{MHz}\right): \delta=0.93\left(\mathrm{t}, 3 \mathrm{H},{ }^{3} \mathrm{~J}_{\mathrm{H}, \mathrm{H}}=7.5 \mathrm{~Hz}\right.$, butyl $\left.\mathrm{CH}_{3}\right)$, 1.31-1.41 (m, 2H, butyl $\left.\mathrm{CH}_{2}\right), 1.61-1.73\left(\mathrm{~m}, 2 \mathrm{H}\right.$, butyl $\left.\mathrm{CH}_{2}\right)$, 1.87, 2.03, 2.07, $2.08\left(4 \times \mathrm{s}, 3 \mathrm{H}, \mathrm{C}(\mathrm{O}) \mathrm{CH}_{3}\right), 2.72\left(\mathrm{t}, 2 \mathrm{H},{ }^{3} J_{\mathrm{H}, \mathrm{H}}=\right.$ $7.5 \mathrm{~Hz}, \mathrm{C}_{\mathrm{trz}} \mathrm{CH}_{2}$ ), 3.99 (ddd, $1 \mathrm{H},{ }^{3} J_{\mathrm{H}, \mathrm{H}}=9.0,5.1,2.1 \mathrm{~Hz}$, glucosyl $\left.\mathrm{C}^{5} \mathrm{H}\right), 4.14\left(\mathrm{dd}, 1 \mathrm{H},{ }^{3} J_{\mathrm{H}, \mathrm{H}}=2.1 \mathrm{~Hz},{ }^{2} J_{\mathrm{H}, \mathrm{H}}=12.6 \mathrm{~Hz}\right.$, glucosyl $\left.\mathrm{C}^{6} \mathrm{H}\right), 4.30\left(\mathrm{dd}, 1 \mathrm{H},{ }^{3} J_{\mathrm{H}, \mathrm{H}}=5.1 \mathrm{~Hz},{ }^{2} J_{\mathrm{H}, \mathrm{H}}=12.6 \mathrm{~Hz}\right.$, glucosyl $\mathrm{C}^{6} \mathrm{H}$ ), 5.23 (app t, 1H, glucosyl $\mathrm{C}^{4} \mathrm{H}$ ), 5.34-5.49 (m, 2H, glucosyl $\mathrm{C}^{2} \mathrm{H}$ and $\left.\mathrm{C}^{3} \mathrm{H}\right), 5.85\left(\mathrm{~d}, 1 \mathrm{H},{ }^{3} J_{\mathrm{H}, \mathrm{H}}=9.0 \mathrm{~Hz}\right.$, glucosyl $\left.\mathrm{C}^{1} \mathrm{H}\right), 7.51$ (s, $\left.1 \mathrm{H}, \mathrm{C}_{\text {trz }} \mathrm{H}\right) .{ }^{13} \mathrm{C}\left\{{ }^{1} \mathrm{H}\right\} \mathrm{NMR}\left(\mathrm{CDCl}_{3}, 100 \mathrm{MHz}\right): \delta=13.9$ (butyl $\mathrm{CH}_{3}$ ), 20.3, 20.66, 20.69, $20.8\left(4 \times \mathrm{C}(\mathrm{O}) \mathrm{CH}_{3}\right), 22.3$ (butyl $\mathrm{CH}_{2}$ ), 25.3 (butyl $\mathrm{CH}_{2}$ ), $31.3\left(\mathrm{C}_{\text {trz }} \mathrm{CH}_{2}\right), 61.7$ (glucosyl $\mathrm{C}^{6} \mathrm{H}_{2}$ ), 67.9, 70.4, 72.9, $75.3\left(4 \times\right.$ glucosyl $\mathrm{C}^{2-5} \mathrm{H}, 85.9$ (glucosyl $\left.\mathrm{C}^{1} \mathrm{H}\right), 119.0$ $\left(\mathrm{C}_{\text {trz }} \mathrm{H}\right), 149.5\left(\mathrm{C}_{\text {trz }}-\mathrm{Bu}\right), 169.1,169.5,170.0,170.6(4 \times \mathrm{C}=\mathrm{O})$. FT-IR (ATR, cm ${ }^{-1}$ ): $3070(\mathrm{w}), 2928(\mathrm{w}), 2357,1746(\mathrm{~s}, \mathrm{C}=\mathrm{O})$, 1436, 1366, 1216 (s), 1093, 1041 (s), 928.

1-(2,3,4,6-Tetra-O-acetyl- $\beta$-D-galactopyranosyl)-4-butyl-1,2,3-triazole (1Gal). Yield: $0.560 \mathrm{~g}(46 \%)$. Anal. calcd for $\mathrm{C}_{20} \mathrm{H}_{29} \mathrm{~N}_{3} \mathrm{O}_{9}$ (455.464 $\mathrm{g} \mathrm{mol}^{-1}$ ): C 52.74, $\mathrm{H} 6.42, \mathrm{~N} \mathrm{9.23 \% ;} \mathrm{found} \mathrm{C} 52.70, \mathrm{H}$ 6.34, N 9.03\%. HRMS (m/z) (ESI+): Calculated for $\mathrm{C}_{20} \mathrm{H}_{30} \mathrm{O}_{9} \mathrm{~N}_{3}{ }^{+}$ $[\mathrm{M}+\mathrm{H}]^{+} \mathrm{m} / \mathrm{z}=456.1977$; found $\mathrm{m} / \mathrm{z}=456.1980$; calculated for $\mathrm{C}_{20} \mathrm{H}_{29} \mathrm{O}_{9} \mathrm{~N}_{3} \mathrm{Na}^{+}[\mathrm{M}+\mathrm{Na}]^{+} \mathrm{m} / z=478.1796$; found $\mathrm{m} / z=$ 478.1799. ${ }^{1} \mathrm{H}$ NMR $\left(400 \mathrm{MHz}, \mathrm{CDCl}_{3}\right): \delta=0.94\left(\mathrm{t}, 3 \mathrm{H},{ }^{3} J_{\mathrm{H}, \mathrm{H}}=\right.$ $7.4 \mathrm{~Hz}$, butyl $\left.\mathrm{CH}_{3}\right), 1.30-1.42\left(\mathrm{~m}, 2 \mathrm{H}\right.$, butyl $\left.\mathrm{CH}_{2}\right), 1.62-1.71(\mathrm{~m}$, $2 \mathrm{H}$, butyl $\left.\mathrm{CH}_{2}\right), 1.88,2.01,2.05,2.22\left(4 \times \mathrm{s}, 3 \mathrm{H}, \mathrm{C}(\mathrm{O}) \mathrm{CH}_{3}\right), 2.73$ $\left(\mathrm{t}, 2 \mathrm{H},{ }^{3} J_{\mathrm{H}, \mathrm{H}}=7.4 \mathrm{~Hz}, \mathrm{C}_{\mathrm{trz}} \mathrm{CH}_{2}\right), 4.11-4.24(\mathrm{~m}, 3 \mathrm{H}$, galactosyl $\left.\mathrm{C}^{5} \mathrm{H}+\mathrm{C}^{6} \mathrm{H}_{2}\right), 5.23\left(\mathrm{dd}, 1 \mathrm{H},{ }^{3} J_{\mathrm{H}, \mathrm{H}}=10.3,3.3 \mathrm{~Hz}\right.$, galactosyl $\left.\mathrm{C}^{4} \mathrm{H}\right)$, 5.50-5.61 (m, 2H, galactosyl $\left.\mathrm{C}^{2} \mathrm{H}+\mathrm{C}^{3} \mathrm{H}\right), 5.81(\mathrm{~d}, 1 \mathrm{H}$, ${ }^{3} J_{\mathrm{H}, \mathrm{H}}=9.3 \mathrm{~Hz}$, galactosyl $\left.\mathrm{C}^{1} \mathrm{H}\right), 7.55\left(\mathrm{~s}, 1 \mathrm{H}, \mathrm{C}_{\mathrm{trz}} \mathrm{H}\right) .{ }^{13} \mathrm{C}\left\{{ }^{1} \mathrm{H}\right\}$ NMR (100 MHz, $\mathrm{CDCl}_{3}$ ): $\delta=13.8$ (butyl $\mathrm{CH}_{3}$ ), 20.2, 20.5, 20.63, $20.64\left(4 \times \mathrm{C}(\mathrm{O}) \mathrm{CH}_{3}\right), 22.2$ (butyl $\mathrm{CH}_{2}$ ), 25.3 (butyl $\mathrm{CH}_{2}$ ), 31.3 $\left(\mathrm{C}_{\text {trz }} \mathrm{CH}_{2}\right.$ ), 61.2 (galactosyl $\mathrm{C}^{6} \mathrm{H}_{2}$ ), 66.9, 67.8, 70.9, 74.0 (galactosyl $\mathrm{C}^{2-5} \mathrm{H}, 86.2$ (galactosyl $\left.\mathrm{C}^{1} \mathrm{H}\right), 118.8\left(\mathrm{C}_{\mathrm{trz}} \mathrm{H}\right), 149.2\left(\mathrm{C}_{\mathrm{trz}}-\mathrm{Bu}\right)$, 169.1, 169.8, 169.9, $170.3(4 \times \mathrm{C}=\mathrm{O})$; FT-IR (ATR, $\left.\mathrm{cm}^{-1}\right): 2958$ (w), 2929 (w), 1743 (s, C=O), 1369, 1218 (s), 1044 (s), 923.

1-(2-(4-Butyl-1,2,3-triazol-1-yl)ethoxy)-1-deoxy-2,3,4,6-tetra- $O$ acetyl- $\beta$-D-glucopyranose (2). The product was prepared according to the general procedure from 2,3,4,6-tetra(O-acetyl)-1-azidoethyl-glucopyranoside (1.250 g, $2.99 \mathrm{mmol}$ ), yielding 2 as a pale yellow oil (1.335 g, 89\%), which was used without further purification. Gradient flash chromatography $\left(\mathrm{SiO}_{2} ; \mathrm{CH}_{2} \mathrm{Cl}_{2}\right.$ to $\left.\mathrm{CH}_{2} \mathrm{Cl}_{2} / \mathrm{CH}_{3} \mathrm{OH} 95: 5\right)$ was used to obtain the product as an off-white hygroscopic solid. HRMS $(\mathrm{m} / \mathrm{z})(\mathrm{ESI}+)$ ): Calculated for $\mathrm{C}_{22} \mathrm{H}_{34} \mathrm{~N}_{3} \mathrm{O}_{10}{ }^{+} \mathrm{m} / z=500.2239[\mathrm{M}+\mathrm{H}]^{+}$; found $m / z=500.2236$. ${ }^{1} \mathrm{H} \mathrm{NMR}\left(300 \mathrm{MHz}, \mathrm{CDCl}_{3}\right): \delta=0.92\left(\mathrm{t}, 3 \mathrm{H},{ }^{3} J_{\mathrm{H}, \mathrm{H}}=7.3 \mathrm{~Hz}\right.$, butyl $\mathrm{CH}_{3}$ ), 1.31-1.48 (m, 2H, butyl $\mathrm{CH}_{2}$ ), 1.57-1.72 (m, 2H, butyl $\left.\mathrm{CH}_{2}\right), 1.93,1.98,2.00,2.07\left(4 \times \mathrm{s}, 3 \mathrm{H}, \mathrm{C}(\mathrm{O}) \mathrm{CH}_{3}\right), 2.56-2.80(\mathrm{~m}$, 
$2 \mathrm{H}$, butyl $\mathrm{CH}_{2}$ ), 3.68 (ddd, $1 \mathrm{H},{ }^{3} \mathrm{~J}_{\mathrm{H}, \mathrm{H}}=10.0,4.8,2.4 \mathrm{~Hz}$, glucosyl $\mathrm{C}^{5} \mathrm{H}$ ), 3.90 (ddd, $1 \mathrm{H},{ }^{2} J_{\mathrm{H}, \mathrm{H}}=10.4 \mathrm{~Hz},{ }^{3} J_{\mathrm{H}, \mathrm{H}}=8.5,3.4 \mathrm{~Hz}$, ethylene $\mathrm{CH} H), 4.06-4.29\left(\mathrm{~m}, 3 \mathrm{H}\right.$, ethylene $\mathrm{CH} \mathrm{H}+$ glucosyl $\left.\mathrm{C}^{6} \mathrm{H}_{2}\right)$, 4.39-4.59 (m, 2H, ethylene $\left.\mathrm{CH}_{2}\right), 4.46\left(\mathrm{~d}, 1 \mathrm{H},{ }^{3} J_{\mathrm{H}, \mathrm{H}}=7.9 \mathrm{~Hz}\right.$, glucosyl $\left.\mathrm{C}^{1} \mathrm{H}\right), 4.98\left(\mathrm{dd}, 1 \mathrm{H},{ }^{3} J_{\mathrm{H}, \mathrm{H}}=9.5,7.9 \mathrm{~Hz}\right.$, glucosyl $\left.\mathrm{C}^{2} \mathrm{H}\right)$, $5.05\left(\mathrm{dd}, 1 \mathrm{H},{ }^{3} J_{\mathrm{H}, \mathrm{H}}=10.0,9.5 \mathrm{~Hz}\right.$, glucosyl $\left.\mathrm{C}^{4} \mathrm{H}\right), 5.16(\mathrm{t}, 1 \mathrm{H}$, ${ }^{3} J_{\mathrm{H}, \mathrm{H}}=9.5 \mathrm{~Hz}$, glucosyl C $\left.{ }^{3} \mathrm{H}\right), 7.31\left(\mathrm{~s}, 1 \mathrm{H}, \mathrm{C}_{\mathrm{trz}} \mathrm{H}\right) .{ }^{13} \mathrm{C}\left\{{ }^{1} \mathrm{H}\right\} \mathrm{NMR}$ (75 $\mathrm{MHz}, \mathrm{CDCl}_{3}$ ): $\delta=13.8$ (butyl $\mathrm{CH}_{3}$ ), 20.5, 20.5, 20.7, 20.7, $\left(4 \times \mathrm{C}(\mathrm{O}) \mathrm{CH}_{3}\right), 22.3,25.4,31.5\left(3 \times\right.$ butyl $\left.\mathrm{CH}_{2}\right), 49.8\left(\mathrm{CH}_{2}\right), 61.8$ $\left(\mathrm{CH}_{2}\right)$, $68.0\left(\mathrm{CH}_{2}\right), 68.3,71.0,72.0,72.5$ (glucosyl $\mathrm{C}^{2-5} \mathrm{H}, 100.6$ (glucosyl $\left.\mathrm{C}^{1} \mathrm{H}\right), 122.0\left(\mathrm{C}_{\mathrm{trz}} \mathrm{H}\right), 148.3\left(\mathrm{C}_{\text {trz }}-\mathrm{Bu}\right), 169.2,169.4$, 170.1, $170.5(4 \times \mathrm{C}=\mathrm{O})$; FT-IR $\left(\right.$ ATR, $\left.\mathrm{cm}^{-1}\right)$ : $2935(\mathrm{w}), 1744(\mathrm{~s}$, $\mathrm{C}=\mathrm{O}), 1432$, 1365, 1211 (s), 1032 (s), 907.

\section{General synthesis of triazolium salts}

The triazole compound $(0.44 \mathrm{mmol})$ and $\mathrm{Me}_{3} \mathrm{OBF}_{4}(0.067 \mathrm{~g}$, $0.45 \mathrm{mmol})$ were dissolved in dry $\mathrm{CH}_{2} \mathrm{Cl}_{2}(30 \mathrm{~mL})$ and stirred at room temperature for $16 \mathrm{~h}$. Then $\mathrm{MeOH}(0.5 \mathrm{~mL})$ was added and stirring continued for $30 \mathrm{~min}$. All volatiles were evaporated under reduced pressure. The residue was dissolved in a minimum of $\mathrm{MeOH}$ and stored at $-20{ }^{\circ} \mathrm{C}$, yielding the triazolium salt as a white solid. 3Gal and $\mathbf{4}$ were hygroscopic and were therefore used without further purification.

1-(2,3,4,6-Tetra-O-acetyl- $\beta$-D-glucopyranosyl)-4-butyl-3-methyl1,2,3-triazol-3-ium tetrafluoroborate (3Glc). According to the general procedure, reaction of 1 Glc $(0.200 \mathrm{~g}, 0.44 \mathrm{mmol})$ and $\mathrm{Me}_{3} \mathrm{OBF}_{4}$ (0.067 mg, $0.45 \mathrm{mmol}$ ) yielded 3Glc (0.240 g, 98\%). Anal. calcd for $\mathrm{C}_{21} \mathrm{H}_{32} \mathrm{~N}_{3} \mathrm{O}_{9} \mathrm{BF}_{4}\left(557.303 \mathrm{~g} \mathrm{~mol}^{-1}\right): \mathrm{C} 45.26, \mathrm{H}$ 5.79, N 7.54\%; found C 45.13, H 5.01, N 7.27\%; HRMS $(\mathrm{m} / \mathrm{z})$ (ESI+): Calculated for $\mathrm{C}_{21} \mathrm{H}_{32} \mathrm{O}_{9} \mathrm{~N}_{3}{ }^{+}\left[\mathrm{M}-\mathrm{BF}_{4}\right]^{+} m / z=470.2133$; found $m / z=470.2136 .{ }^{1} \mathrm{H} \mathrm{NMR}\left(400 \mathrm{MHz}, \mathrm{CDCl}_{3}\right): \delta=1.00(\mathrm{t}$, $3 \mathrm{H},{ }^{3} J_{\mathrm{H}, \mathrm{H}}=7.3 \mathrm{~Hz}$, butyl $\left.\mathrm{CH}_{3}\right), 1.39-1.54\left(\mathrm{~m}, 2 \mathrm{H}\right.$, butyl $\left.\mathrm{CH}_{2}\right)$, 1.69-1.83 (m, 2H, butyl $\left.\mathrm{CH}_{2}\right), 2.02,2.03,2.06,2.08(4 \times \mathrm{s}, 3 \mathrm{H}$, $\left.\mathrm{C}(\mathrm{O}) \mathrm{CH}_{3}\right), 2.75-2.99\left(\mathrm{~m}, 2 \mathrm{H}\right.$, butyl $\left.\mathrm{CH}_{2}\right), 4.12-4.45(\mathrm{~m}, 6 \mathrm{H}$, glucosyl $\left.\mathrm{C}^{5} \mathrm{H}+\mathrm{C}^{6} \mathrm{H}_{2}+\mathrm{NCH}_{3}\right), 5.26\left(\mathrm{t}, 1 \mathrm{H},{ }^{3} \mathrm{~J}_{\mathrm{H}, \mathrm{H}}=9.5 \mathrm{~Hz}\right.$, glucosyl $\left.\mathrm{C}^{4} \mathrm{H}\right), 5.42\left(\mathrm{t}, 1 \mathrm{H},{ }^{3} \mathrm{~J}_{\mathrm{H}, \mathrm{H}}=9.5 \mathrm{~Hz}\right.$, glucosyl $\left.\mathrm{C}^{3} \mathrm{H}\right), 5.62(\mathrm{t}, 1 \mathrm{H}$, ${ }^{3} J_{\mathrm{H}, \mathrm{H}}=9.0 \mathrm{~Hz}$, glucosyl C $\left.{ }^{2} \mathrm{H}\right), 6.20\left(\mathrm{~d}, 1 \mathrm{H},{ }^{3} J_{\mathrm{H}, \mathrm{H}}=9.0 \mathrm{~Hz}\right.$, glucosyl $\left.\mathrm{C}^{1} \mathrm{H}\right), 8.56$ (s, $\left.1 \mathrm{H}, \mathrm{C}_{\text {trz }} \mathrm{H}\right) .{ }^{13} \mathrm{C}\left\{{ }^{1} \mathrm{H}\right\}$ NMR (100 MHz, $\left.\mathrm{CDCl}_{3}\right)$ : $\delta=13.7$ (butyl $\left.\mathrm{CH}_{3}\right), 20.5,20.70,20.74,20.9\left(4 \times \mathrm{C}(\mathrm{O}) \mathrm{CH}_{3}\right)$, 22.3, 23.4, $28.9\left(3 \times\right.$ butyl $\left.\mathrm{CH}_{2}\right), 38.4\left(\mathrm{NCH}_{3}\right), 61.2$ (glucosyl $\mathrm{C}^{6} \mathrm{H}_{2}$ ), 67.3, 69.6, 72.9, 75.5 (galactosyl $\mathrm{C}^{2-5} \mathrm{H}, 87.5$ (glucosyl $\left.\mathrm{C}^{1} \mathrm{H}\right), 128.6\left(\mathrm{C}_{\mathrm{trz}} \mathrm{H}\right), 145.8\left(\mathrm{C}_{\mathrm{trz}}-\mathrm{Bu}\right), 169.6,169.87,169.93$, $170.7(4 \times \mathrm{C}=\mathrm{O})$; FT-IR (ATR, $\left.\mathrm{cm}^{-1}\right): 2968(\mathrm{w}), 2359,1747$ (s, $\mathrm{C}=\mathrm{O}), 1434,1371$ (s), 1215 (s), 1024 (br, s, BF 4 ), 927.

1-(2,3,4,6-Tetra-O-acetyl- $\beta$-D-galactopyranosyl)-4-butyl-3-methyl1,2,3-triazol-3-ium tetrafluoroborate (3Gal). According to the general procedure, $1 \mathrm{Gal}(0.200 \mathrm{~g}, 0.44 \mathrm{mmol})$ and $\mathrm{Me}_{3} \mathrm{OBF}_{4}$ $(0.067 \mathrm{mg}, 0.45 \mathrm{mmol})$ were reacted to yield 3Gal $(0.246 \mathrm{~g}$, 100\%). HRMS $(\mathrm{m} / \mathrm{z})$ (ESI+): Calculated for $\mathrm{C}_{21} \mathrm{H}_{32} \mathrm{O}_{9} \mathrm{~N}_{3}{ }^{+}$ $\left[\mathrm{M}-\mathrm{BF}_{4}\right]^{+} \mathrm{m} / z=470.2133$; found $m / z=470.2127 .{ }^{1} \mathrm{H} \mathrm{NMR}$ $\left(300 \mathrm{MHz} \mathrm{CDCl}_{3}\right): \delta=0.99\left(\mathrm{t}, 3 \mathrm{H},{ }^{3} \mathrm{~J}_{\mathrm{H}, \mathrm{H}}=7.3 \mathrm{~Hz}\right.$, butyl $\left.\mathrm{CH}_{3}\right)$, 1.39-1.56 (m, 2H, butyl $\mathrm{CH}_{2}$ ), 1.64-1.82 (m, 2H, butyl $\mathrm{CH}_{2}$ ), 2.01, 2.04, 2.07, $2.21\left(4 \times \mathrm{s}, 3 \mathrm{H}, \mathrm{C}(\mathrm{O}) \mathrm{CH}_{3}\right), 2.77-2.97(\mathrm{~m}, 2 \mathrm{H}$, butyl $\left.\mathrm{CH}_{2}\right)$, 4.10-4.46 (m, 6H, galactosyl $\left.\mathrm{C}^{5} \mathrm{H}+\mathrm{C}^{6} \mathrm{H}_{2}+\mathrm{NCH}_{3}\right)$, $5.31\left(\mathrm{dd}, 1 \mathrm{H},{ }^{3} J_{\mathrm{H}, \mathrm{H}}=10.1,3.3 \mathrm{~Hz}\right.$, galactosyl $\left.\mathrm{C}^{3} \mathrm{H}\right), 5.56(\mathrm{~d}, 1 \mathrm{H}$, ${ }^{3} J_{\mathrm{H}, \mathrm{H}}=3.3 \mathrm{~Hz}$, galactosyl $\left.\mathrm{C}^{4} \mathrm{H}\right), 5.67\left(\mathrm{t}, 1 \mathrm{H},{ }^{3} J_{\mathrm{H}, \mathrm{H}}=9.5 \mathrm{~Hz}\right.$, galactosyl $\left.\mathrm{C}^{2} \mathrm{H}\right), 6.12\left(\mathrm{~d}, 1 \mathrm{H},{ }^{3} J_{\mathrm{H}, \mathrm{H}}=9.5 \mathrm{~Hz}\right.$, galactosyl $\left.\mathrm{C}^{1} \mathrm{H}\right)$, $8.50\left(\mathrm{~s}, 1 \mathrm{H}, \mathrm{C}_{\text {trz }} \mathrm{H}\right) .{ }^{13} \mathrm{C}\left\{{ }^{1} \mathrm{H}\right\}$ NMR $\left(100 \mathrm{MHz}, \mathrm{CDCl}_{3}\right): \delta=13.6$ (butyl $\mathrm{CH}_{3}$ ), 20.4, 20.5, 20.7, $20.7\left(4 \times \mathrm{C}(\mathrm{O}) \mathrm{CH}_{3}\right), 22.2,23.3$, $28.9\left(3 \times\right.$ butyl $\left.\mathrm{CH}_{2}\right), 38.2\left(\mathrm{~N}-\mathrm{CH}_{3}\right), 60.8$ (galactosyl $\left.\mathrm{C}^{6} \mathrm{H}_{2}\right), 66.8$, 67.2, 70.7, 74.8 (galactosyl $\mathrm{C}^{2-5} \mathrm{H}, 88.0$ (galactosyl $\mathrm{C}^{1} \mathrm{H}$ ), 128.0 $\left(\mathrm{C}_{\text {trz }} \mathrm{H}\right), 145.7\left(\mathrm{C}_{\text {trz }}-\mathrm{Bu}\right), 169.6,169.9,170.0,170.5(4 \times \mathrm{C}=\mathrm{O})$; FT-IR (ATR, cm ${ }^{-1}$ ): $3121(\mathrm{w}), 2962(\mathrm{w}), 1745(\mathrm{~s}, \mathrm{C}=\mathrm{O}), 1370$, 1210 (s), 1034 (s, br, BF 4 ), 922, 496.

1-(2-(4-Butyl-3-methyl-1,2,3-triazolium-1-yl)ethoxy)-1-deoxy2,3,4,6-tetra- $O$-acetyl- $\beta$-D-glucopyranose tetrafluoroborate (4). According to the general procedure, $2(0.250 \mathrm{~g}, 0.50 \mathrm{mmol})$ and $\mathrm{Me}_{3} \mathrm{OBF}_{4}(0.075 \mathrm{mg}, 0.51 \mathrm{mmol})$ were reacted and yielded $4(0.255 \mathrm{~g}$, 84\%). HRMS $(\mathrm{m} / \mathrm{z}) \quad(\mathrm{ESI}+)$ : Calculated for $\mathrm{C}_{23} \mathrm{H}_{36} \mathrm{O}_{10} \mathrm{~N}_{3}{ }^{+} \mathrm{m} / \mathrm{z}=514.2395\left[\mathrm{M}-\mathrm{BF}_{4}\right]^{+}$; found $\mathrm{m} / \mathrm{z}=$ 514.2387. ${ }^{1} \mathrm{H}$ NMR $\left(400 \mathrm{MHz}, \mathrm{CDCl}_{3}\right): \delta=0.92\left(\mathrm{t}, 3 \mathrm{H},{ }^{3} J_{\mathrm{H}, \mathrm{H}}=\right.$ $7.3 \mathrm{~Hz}$, butyl $\mathrm{CH}_{3}$ ), 1.41 (quintet, $2 \mathrm{H}^{3} J_{\mathrm{H}, \mathrm{H}}=7.4 \mathrm{~Hz}$, butyl $\mathrm{CH}_{2}$ ), 1.60-1.75 (m, 2H, butyl $\left.\mathrm{CH}_{2}\right), 1.92,1.95,1.96,2.01(4 \times \mathrm{s}, 3 \mathrm{H}$, $\left.\mathrm{C}(\mathrm{O}) \mathrm{CH}_{3}\right), 2.67-2.86\left(\mathrm{~m}, 2 \mathrm{H}\right.$, butyl $\left.\mathrm{CH}_{2}\right), 3.75$ (ddd, $1 \mathrm{H}, \mathrm{J}=$ 10.2, 4.7, $2.3 \mathrm{~Hz}$, glucosyl $\left.\mathrm{C}^{5} \mathrm{H}\right), 4.00-4.28\left(\mathrm{~m}, 7 \mathrm{H}, \mathrm{NCH}_{3}+\right.$ ethylene $\mathrm{CH}_{2}+$ glucosyl $\left.\mathrm{C}^{6} \mathrm{H}_{2}\right), 4.60\left(\mathrm{~d}, 1 \mathrm{H},{ }^{3} J_{\mathrm{H}, \mathrm{H}}=7.9 \mathrm{~Hz}\right.$, glucosyl $\left.\mathrm{C}^{1} \mathrm{H}\right)$, 4.64-4.79 (m, 2H, ethylene $\left.\mathrm{CH}_{2}\right), 4.82(\mathrm{dd}, 1 \mathrm{H}$, ${ }^{3} J_{\mathrm{H}, \mathrm{H}}=9.6,7.9 \mathrm{~Hz}$, glucosyl $\left.\mathrm{C}^{2} \mathrm{H}\right), 4.95\left(\mathrm{t}, 1 \mathrm{H},{ }^{3} J_{\mathrm{H}, \mathrm{H}}=9.6 \mathrm{~Hz}\right.$, glucosyl $\left.\mathrm{C}^{4} \mathrm{H}\right), 5.12\left(\mathrm{t}, 1 \mathrm{H},{ }^{3} \mathrm{~J}_{\mathrm{H}, \mathrm{H}}=9.6 \mathrm{~Hz}\right.$, glucosyl $\left.\mathrm{C}^{3} \mathrm{H}\right), 8.17(\mathrm{~s}$, $\left.1 \mathrm{H}, \mathrm{C}_{\mathrm{trz}} \mathrm{H}\right) .{ }^{13} \mathrm{C}\left\{{ }^{1} \mathrm{H}\right\}$ NMR (100 MHz, $\mathrm{CDCl}_{3}$ ): $\delta=13.3$ (butyl $\left.\mathrm{CH}_{3}\right), 20.4,20.4,20.46,20.53\left(4 \times \mathrm{OC}(\mathrm{O}) \mathrm{CH}_{3}\right), 21.9,22.7,28.5$ $\left(3 \times\right.$ butyl $\left.\mathrm{CH}_{2}\right), 37.2\left(\mathrm{~N}-\mathrm{CH}_{3}\right), 53.6$ (ethylene $\left.\mathrm{CH}_{2}\right), 61.5$ (glucosyl $\mathrm{C}^{6} \mathrm{H}_{2}$ ), 66.5 (ethylene $\mathrm{CH}_{2}$ ), 68.1, 71.0, 71.7, 72.4 (glucosyl $\mathrm{C}^{2-5} \mathrm{H}, 100.4$ (glucosyl $\left.\mathrm{C}^{1} \mathrm{H}\right), 128.4\left(\mathrm{C}_{\mathrm{trz}} \mathrm{H}\right), 144.5\left(\mathrm{C}_{\mathrm{trz}}-\mathrm{Bu}\right)$, 169.4, 169.6, 169.8, $170.5(4 \times \mathrm{C}=\mathrm{O})$; FT-IR $\left(\mathrm{ATR}, \mathrm{cm}^{-1}\right): 2959$ (w), 2848(w), $1744(\mathrm{~s}, \mathrm{C}=\mathrm{O}), 1435,1369,1218$ (s), 1034 (s, br, $\left.\mathrm{BF}_{4}\right), 908$.

\section{General synthesis of $\mathrm{Ru}(\mathrm{II})$ complexes}

The triazolium salt $(0.43 \mathrm{mmol}), \mathrm{Ag}_{2} \mathrm{O}(0.060 \mathrm{~g}, 0.26 \mathrm{mmol})$ and $\mathrm{Me}_{4} \mathrm{NCl}(0.057 \mathrm{~g}, 0.52 \mathrm{mmol})$ were suspended in dry $\mathrm{CH}_{3} \mathrm{CN}(50 \mathrm{~mL})$ and stirred in the absence of light at room temperature for $5 \mathrm{~h}$. The reaction mixture was diluted with $\mathrm{CH}_{2} \mathrm{Cl}_{2}(25 \mathrm{~mL})$, filtered through Celite and concentrated under reduced pressure. $\mathrm{CH}_{2} \mathrm{Cl}_{2}(20 \mathrm{~mL})$ and $\left[\mathrm{Ru}(p \text {-cym }) \mathrm{Cl}_{2}\right]_{2}$ $(0.099 \mathrm{~g}, 0.16 \mathrm{mmol})$ were added and the mixture was stirred for $3 \mathrm{~h}$. The reaction mixture was cooled in an ice bath, filtered through Celite, and evaporated to dryness. The red residue was purified by gradient flash chromatography $\left(\mathrm{SiO}_{2} ; \mathrm{CH}_{2} \mathrm{Cl}_{2}\right.$ to $\mathrm{CH}_{2} \mathrm{Cl}_{2}$ /acetone $9: 1$ ).

\section{Ru complex 5Glc}

From 3Glc $(0.240 \mathrm{~g})$ according to the general procedure, 5Glc was obtained $(0.189 \mathrm{~g}, 80 \%)$. Anal. calcd for $\mathrm{C}_{31} \mathrm{H}_{45} \mathrm{~N}_{3} \mathrm{O}_{9} \mathrm{RuCl}_{2}$ (775.683 $\left.\mathrm{g} \mathrm{mol}^{-1}\right): \mathrm{C} 48.00, \mathrm{H} \mathrm{5.85}, \mathrm{N} \mathrm{5.42 \%}$; found C 48.06, $\mathrm{H}$ 5.39, N 5.84\%. HRMS $(\mathrm{m} / \mathrm{z})$ (ESI+): Calculated for $\mathrm{C}_{31} \mathrm{H}_{45} \mathrm{~N}_{3} \mathrm{O}_{9} \mathrm{RuCl}^{+} \mathrm{m} / z=740.1882[\mathrm{M}-\mathrm{Cl}]^{+}$; found $m / z=$ 740.1885. ${ }^{1} \mathrm{H}$ NMR $\left(400 \mathrm{MHz}, \mathrm{CDCl}_{3}\right): \delta=0.95\left(\mathrm{t}, 3 \mathrm{H},{ }^{3} J_{\mathrm{H}, \mathrm{H}}=\right.$ $7.3 \mathrm{~Hz}$, butyl $\mathrm{CH}_{3}$ ), 1.32 (d, $\left.3 \mathrm{H},{ }^{3} J_{\mathrm{H}, \mathrm{H}}=6.9 \mathrm{~Hz}, \mathrm{CHCH}_{3}\right), 1.34$ (d, $3 \mathrm{H},{ }^{3} J_{\mathrm{H}, \mathrm{H}}=6.9 \mathrm{~Hz}, \mathrm{CHCH}_{3}$ ), 1.46 (quintet, $2 \mathrm{H},{ }^{3} J_{\mathrm{H}, \mathrm{H}}=$ $7.3 \mathrm{~Hz}$, butyl $\mathrm{CH}_{2}$ ), 1.54-1.64 (br s, 2H, butyl $\mathrm{CH}_{2}$ ), $1.93(\mathrm{~s}, 3 \mathrm{H}$, $\left.\mathrm{C}(\mathrm{O}) \mathrm{CH}_{3}\right), 1.97\left(\mathrm{~s}, 3 \mathrm{H}, \mathrm{cym}-\mathrm{CH}_{3}\right), 2.02,2.04,2.06(3 \times \mathrm{s}, 3 \mathrm{H}$, 
$\left.\mathrm{C}(\mathrm{O}) \mathrm{CH}_{3}\right), 2.88-3.08\left(\mathrm{~m}, 3 \mathrm{H}\right.$, butyl $\left.\mathrm{CH}_{2}+\mathrm{CHMe}_{2}\right), 3.97-4.09$ $\left(\mathrm{m}, 4 \mathrm{H}, \mathrm{NCH}_{3}+\right.$ glucosyl $\left.\mathrm{C}^{5} \mathrm{H}\right), 4.12-4.27(\mathrm{~m}, 2 \mathrm{H}$, glucosyl $\left.\mathrm{C}^{6} \mathrm{H}_{2}\right), 5.00\left(\mathrm{~d}, 1 \mathrm{H},{ }^{3} J_{\mathrm{H}, \mathrm{H}}=5.8 \mathrm{~Hz}, \mathrm{C}_{\mathrm{cym}} \mathrm{H}\right), 5.14-5.26(\mathrm{~m}, 2 \mathrm{H}$, $\mathrm{C}_{\text {cym }} \mathrm{H}+$ glucosyl $\left.\mathrm{C}^{4} \mathrm{H}\right), 5.30-5.43\left(\mathrm{~m}, 2 \mathrm{H}, \mathrm{C}_{\text {cym }} \mathrm{H}+\right.$ glucosyl $\left.\mathrm{C}^{3} \mathrm{H}\right), 5.53\left(\mathrm{~d}, 1 \mathrm{H},{ }^{3} J_{\mathrm{H}, \mathrm{H}}=5.8 \mathrm{~Hz}, \mathrm{C}_{\mathrm{cym}} \mathrm{H}\right), 6.01\left(\mathrm{t}, 1 \mathrm{H},{ }^{3} J_{\mathrm{H}, \mathrm{H}}=\right.$ $9.4 \mathrm{~Hz}$, glucosyl $\mathrm{C}^{2} \mathrm{H}$ ), 6.76 (br s, $1 \mathrm{H}$, glucosyl $\mathrm{C}^{1} \mathrm{H}$ ). ${ }^{13} \mathrm{C}\left\{{ }^{1} \mathrm{H}\right\}$ NMR (100 MHz, $\left.\mathrm{CDCl}_{3}\right): \delta=14.0\left(\right.$ butyl $\left.\mathrm{CH}_{3}\right), 18.8\left(\mathrm{cym}-\mathrm{CH}_{3}\right)$, 20.71, 20.74, 20.97, $21.12\left(4 \times \mathrm{C}(\mathrm{O}) \mathrm{CH}_{3}\right), 22.7,23.0(2 \times$ $\mathrm{CH}-\mathrm{CH}_{3}$ ), 23.2 (butyl $\mathrm{CH}_{2}$ ), 26.3 (butyl $\mathrm{CH}_{2}$ ), $30.8\left(\mathrm{CHMe}_{2}\right.$ ), 31.8 (butyl $\mathrm{CH}_{2}$ ), $37.3\left(\mathrm{NCH}_{3}\right.$ ), 62.3 (glucosyl $\mathrm{C}^{6} \mathrm{H}_{2}$ ), 68.3 (glucosyl $\mathrm{C}^{4} \mathrm{H}$ ), 70.1 (glucosyl $\mathrm{C}^{2} \mathrm{H}$ ), 74.1 (glucosyl $\mathrm{C}^{3} \mathrm{H}$ ), 74.5 (glucosyl $\mathrm{C}^{5} \mathrm{H}$ ), 81.1, 81.9, 86.3, $86.8\left(4 \times \mathrm{C}_{\text {cym }} \mathrm{H}\right), 87.1$ (glucosyl $\left.\mathrm{C}^{1} \mathrm{H}\right), 97.6\left(\mathrm{C}_{\text {cym }}\right), 108.3\left(\mathrm{C}_{\text {cym }}\right), 148.0\left(\mathrm{C}_{\mathrm{trz}}-\mathrm{Bu}\right), 167.1\left(\mathrm{C}_{\mathrm{trz}}-\mathrm{Ru}\right)$, 169.2, 169.6, 170.1, $170.5(4 \times \mathrm{C}=\mathrm{O})$; FT-IR $\left(\mathrm{ATR}, \mathrm{cm}^{-1}\right): 2957$ (w), $1747(\mathrm{~s}, \mathrm{C}=\mathrm{O}), 1433,1365,1212$ (s), 1032, 922.

\section{Ru complex 5Gal}

From 3Gal ( $0.223 \mathrm{~g})$ according to the general procedure, 5Gal was obtained $(0.138 \mathrm{~g}, 60 \%)$. Anal. calcd for $\mathrm{C}_{31} \mathrm{H}_{45} \mathrm{~N}_{3} \mathrm{O}_{9} \mathrm{RuCl}_{2}$ (775.683 $\mathrm{g} \mathrm{mol}^{-1}$ ), C 48.00, H 5.85, N 5.42\%; found C 47.37, H 5.65, N 5.00\%. HRMS $(\mathrm{m} / \mathrm{z}) \quad(\mathrm{ESI}+)$ : Calculated for $\mathrm{C}_{31} \mathrm{H}_{45} \mathrm{~N}_{3} \mathrm{O}_{9} \mathrm{RuCl}^{+} \mathrm{m} / \mathrm{z}=740.1882[\mathrm{M}-\mathrm{Cl}]^{+}$; found $\mathrm{m} / \mathrm{z}=$ 740.1886. ${ }^{1} \mathrm{H}$ NMR $\left(400 \mathrm{MHz}, \mathrm{CDCl}_{3}\right): \delta=0.95\left(\mathrm{t}, 3 \mathrm{H},{ }^{3} J_{\mathrm{H}, \mathrm{H}}=\right.$ $7.2 \mathrm{~Hz}$, butyl $\left.\mathrm{CH}_{3}\right), 1.30,1.33\left(2 \times \mathrm{d}, 3 \mathrm{H},{ }^{3} J_{\mathrm{H}, \mathrm{H}}=6.9 \mathrm{~Hz}\right.$, $\mathrm{CHCH}_{3}$ ), 1.40-1.55 (m, 2H, butyl $\mathrm{CH}_{2}$ ), 1.60-1.90 (br s, 2H, butyl $\mathrm{CH}_{2}$ ), 1.92 (s, 3H, C(O) $\left.\mathrm{CH}_{3}\right), 1.97$ (s, 3H, cym- $\left.\mathrm{CH}_{3}\right), 1.99$, 2.02, $2.23\left(3 \times \mathrm{s}, 3 \mathrm{H}, \mathrm{C}(\mathrm{O}) \mathrm{CH}_{3}\right), 2.85-3.14\left(\mathrm{~m}, 3 \mathrm{H}\right.$, butyl $\mathrm{CH}_{2}+$ $\left.\mathrm{CHMe}_{2}\right), 4.08\left(\mathrm{~s}, 3 \mathrm{H}, \mathrm{NCH}_{3}\right), 4.11-4.28\left(\mathrm{~m}, 3 \mathrm{H}\right.$, galactosyl $\mathrm{C}^{5} \mathrm{H}$ $\left.+\mathrm{C}^{6} \mathrm{H}_{2}\right), 4.97\left(\mathrm{~d}, 1 \mathrm{H},{ }^{3} \mathrm{~J}_{\mathrm{H}, \mathrm{H}}=5.8 \mathrm{~Hz}, \mathrm{C}_{\mathrm{cym}} \mathrm{H}\right), 5.15-5.26(\mathrm{~m}, 2 \mathrm{H}$, $\mathrm{C}_{\text {cym }} \mathrm{H}+$ galactosyl $\left.\mathrm{CH}\right), 5.37\left(\mathrm{~d}, 1 \mathrm{H},{ }^{3} J_{\mathrm{H}, \mathrm{H}}=5.8 \mathrm{~Hz}, \mathrm{C}_{\text {cym }} \mathrm{H}\right)$, 5.46-5.63 (m, 2H, $\mathrm{C}_{\text {cym }} \mathrm{H}+$ galactosyl $\left.\mathrm{CH}\right), 6.17\left(\mathrm{t}, 1 \mathrm{H},{ }^{3} J_{\mathrm{H}, \mathrm{H}}=\right.$ 9.7 Hz, galactosyl $\mathrm{C}^{2} \mathrm{H}$ ), 6.86 (br s, $1 \mathrm{H}$, galactosyl $\left.\left.\mathrm{C}^{1} \mathrm{H}\right) .{ }^{13} \mathrm{C}^{1} \mathrm{H}\right\}$ NMR (100 MHz, $\left.\mathrm{CDCl}_{3}\right): \delta=14.0$ (butyl $\left.\mathrm{CH}_{3}\right), 18.8\left(\mathrm{cym}-\mathrm{CH}_{3}\right)$, 20.6, 20.90, 20.92, $21.26\left(4 \times \mathrm{C}(\mathrm{O}) \mathrm{CH}_{3}\right), 22.4\left(\mathrm{CHCH}_{3}\right), 23.2$ (butyl $\mathrm{CH}_{2}$ ), $26.3\left(\mathrm{CHMe}_{2}\right.$ ), 31.1 (butyl $\mathrm{CH}_{2}$ ), 31.8 (butyl $\mathrm{CH}_{2}$ ), $37.2\left(\mathrm{NCH}_{3}\right), 62.1$ (galactosyl $\left.\mathrm{C}^{6} \mathrm{H}_{2}\right), 67.5$ (galactosyl $\mathrm{C}^{2} \mathrm{H}$ ), 68.4 (galactosyl $\mathrm{C}^{3} \mathrm{H}$ ), 72.1 (galactosyl $\mathrm{C}^{4} \mathrm{H}$ ), 73.7 (galactosyl $\mathrm{C}^{5} \mathrm{H}$ ), 80.7, 81.9, 86.0, $87.0\left(4 \times \mathrm{C}_{\text {cym }} \mathrm{H}\right), 87.6$ (galactosyl $\left.\mathrm{C}^{1} \mathrm{H}\right), 98.1$ $\left(\mathrm{C}_{\text {cym }}\right), 108.3\left(\mathrm{C}_{\text {cym }}\right), 148.0\left(\mathrm{C}_{\mathrm{trz}}-\mathrm{Bu}\right), 167.1\left(\mathrm{C}_{\mathrm{trz}}-\mathrm{Ru}\right), 169.5$, 169.9, 170.27, $170.28(4 \times \mathrm{C}=\mathrm{O})$; FT-IR $\left(\mathrm{ATR}, \mathrm{cm}^{-1}\right)$ : $2956(\mathrm{w})$, $1748(\mathrm{~s}, \mathrm{C}=\mathrm{O}), 1367,1216(\mathrm{~s}), 1051,921$.

\section{Ru complex 6}

Reaction of $4(0.220 \mathrm{~g})$ according to the general procedure afforded complex $6(0.096 \mathrm{~g}, 30 \%)$. Anal. calcd for $\mathrm{C}_{33} \mathrm{H}_{49} \mathrm{~N}_{3} \mathrm{O}_{10} \mathrm{RuCl}_{2} \cdot\left(\mathrm{H}_{2} \mathrm{O}\right)$ (837.751 $\left.\mathrm{g} \mathrm{mol}^{-1}\right), \mathrm{C}$ 47.31, H 6.14, $\mathrm{N} 5.02 \%$; found C 47.49, H 5.89, N 4.70\%. HRMS (m/z) (ESI+): Calculated for $\mathrm{C}_{33} \mathrm{H}_{49} \mathrm{~N}_{3} \mathrm{O}_{10} \mathrm{RuCl}^{+} \mathrm{m} / z=784.2144[\mathrm{M}-\mathrm{Cl}]^{+}$; found $m / z=784.2153 .{ }^{1} \mathrm{H} \mathrm{NMR}\left(400 \mathrm{MHz}, \mathrm{CDCl}_{3}\right): \delta=0.96(\mathrm{t}$, $3 \mathrm{H},{ }^{3} J_{\mathrm{H}, \mathrm{H}}=7.3 \mathrm{~Hz}$, butyl $\left.\mathrm{CH}_{3}\right), 1.30\left(\mathrm{~d}, 6 \mathrm{H},{ }^{3} J_{\mathrm{H}, \mathrm{H}}=6.9 \mathrm{~Hz}\right.$, $\left.\mathrm{CHCH}_{3}\right), 1.46\left(\mathrm{~m}, 2 \mathrm{H}\right.$, butyl $\left.\mathrm{CH}_{2}\right), 1.55-1.70$ (br s, 2H, butyl $\mathrm{CH}_{2}$ ), 1.98 (s, 3H, C(O) $\mathrm{CH}_{3}$ ), 1.99-2.04 (m, 9H, cym- $\mathrm{CH}_{3}+2 \times$ $\left.\mathrm{C}(\mathrm{O}) \mathrm{CH}_{3}\right), 2.07$ (s, 3H, C(O) $\left.\mathrm{CH}_{3}\right), 2.86-3.09\left(\mathrm{~m}, 3 \mathrm{H}\right.$, butyl $\mathrm{CH}_{2}+$ $\mathrm{CHMe}_{2}$ ), 3.75 (ddd, $1 \mathrm{H},{ }^{3} J_{\mathrm{H}, \mathrm{H}}=10.1,4.6,2.4 \mathrm{~Hz}$, glucosyl $\mathrm{C}^{5} \mathrm{H}$ ), $3.98\left(\mathrm{~s}, 3 \mathrm{H}, \mathrm{NCH}_{3}\right), 4.08-4.19(\mathrm{~m}, 2 \mathrm{H}$, ethylene $\mathrm{CH} \mathrm{H}+$ glucosyl $\left.\mathrm{C}^{6} \mathrm{HH}\right), 4.22-4.38\left(\mathrm{~m}, 2 \mathrm{H}\right.$, ethylene $\mathrm{CH} H+$ glucosyl $\left.\mathrm{C}^{6} \mathrm{H} H\right), 4.65$ $\left(\mathrm{d}, 1 \mathrm{H},{ }^{3} J_{\mathrm{H}, \mathrm{H}}=8.0 \mathrm{~Hz}\right.$, glucosyl $\left.\mathrm{C}^{1} \mathrm{H}\right), 4.83\left(\mathrm{dtd}, 2 \mathrm{H},{ }^{2} J_{\mathrm{H}, \mathrm{H}}=\right.$ $14.0,{ }^{3} J_{\mathrm{H}, \mathrm{H}}=8.0,5.8 \mathrm{~Hz}$, ethylene $\left.\mathrm{CH}_{2}\right), 4.95\left(\mathrm{dd}, 1 \mathrm{H},{ }^{3} J_{\mathrm{H}, \mathrm{H}}=\right.$ 9.5, 8.0 Hz, glucosyl $\left.\mathrm{C}^{2} \mathrm{H}\right), 5.07-5.14\left(\mathrm{~m}, 3 \mathrm{H}\right.$, glucosyl $\mathrm{C}^{4} \mathrm{H}+$ $\left.\mathrm{C}_{\text {cym }} \mathrm{H}\right), 5.20\left(\mathrm{t}, 1 \mathrm{H},{ }^{3} J_{\mathrm{H}, \mathrm{H}}=9.5 \mathrm{~Hz}\right.$, glucosyl $\left.\mathrm{C}^{3} \mathrm{H}\right), 5.37(\mathrm{dd}, 1 \mathrm{H}$, $\left.{ }^{3} J_{\mathrm{H}, \mathrm{H}}=5.8,1.3 \mathrm{~Hz}, \mathrm{C}_{\text {cym }} \mathrm{H}\right), 5.40\left(\mathrm{dd}, 1 \mathrm{H},{ }^{3} J_{\mathrm{H}, \mathrm{H}}=5.8,1.3 \mathrm{~Hz}\right.$, $\mathrm{C}_{\text {cym }} \mathrm{H}$ ). ${ }^{13} \mathrm{C}\left\{{ }^{1} \mathrm{H}\right\}$ NMR (100 MHz, $\mathrm{CDCl}_{3}$ ): $\delta=13.9$ (butyl $\mathrm{CH}_{3}$ ), $18.5\left(\mathrm{cym}-\mathrm{CH}_{3}\right), 20.59,20.61,20.8,22.5\left(4 \times \mathrm{C}(\mathrm{O}) \mathrm{CH}_{3}\right), 22.8$ $\left(\mathrm{CHCH}_{3}\right), 23.1$ (butyl $\left.\mathrm{CH}_{2}\right), 26.0\left(\mathrm{CHMe}_{2}\right), 30.7$ (butyl $\mathrm{CH}_{2}$ ), 31.8 (butyl $\mathrm{CH}_{2}$ ), $36.4\left(\mathrm{NCH}_{3}\right.$ ), 53.8 (ethylene $\mathrm{CH}_{2}$ ), 61.9 (glucosyl $\mathrm{C}^{6} \mathrm{H}_{2}$ ), 68.3 (glucosyl $\mathrm{CH}$ ), 68.7 (ethylene $\mathrm{CH}_{2}$ ), 71.4, 71.9, $72.9(3 \times$ glucosyl $\mathrm{CH}), 82.4,82.9,85.1,85.2\left(4 \times \mathrm{C}_{\text {cym }} \mathrm{H}\right), 96.7$ $\left(\mathrm{C}_{\text {cym }}\right), 100.5$ (glucosyl $\left.\mathrm{C}^{1} \mathrm{H}\right), 107.4\left(\mathrm{C}_{\text {cym }}\right), 147.6\left(\mathrm{C}_{\text {trz }}-\mathrm{Bu}\right)$, $163.0\left(\mathrm{C}_{\mathrm{trz}}-\mathrm{Ru}\right), 169.2,169.5,170.1,170.6(4 \times \mathrm{C}=\mathrm{O})$.

\section{In situ deprotection of $5 \mathrm{Glc}$}

Complex 5Glc $(4 \mathrm{mg}, 5 \mu \mathrm{mol})$ was dissolved in $\mathrm{D}_{2} \mathrm{O}(0.5 \mathrm{~mL})$ and $\mathrm{KOH}\left(0.2 \mathrm{M}\right.$ in $\left.\mathrm{D}_{2} \mathrm{O}, 0.05 \mathrm{~mL}, 0.05 \mathrm{mmol}\right)$ was added, which induces an immediate color change from orange to yellow. HRMS $(m / z)(E S I+)$ : Calculated for $\mathrm{C}_{23} \mathrm{H}_{36} \mathrm{~N}_{3} \mathrm{O}_{5} \mathrm{Ru}^{+} \mathrm{m} / z=$ 536.1704 $[\mathrm{M}-2 \mathrm{Cl}-\mathrm{H}]^{+}$; found $m / z=536.1684 .{ }^{1} \mathrm{H} \mathrm{NMR}$ $\left(300 \mathrm{MHz}, \mathrm{D}_{2} \mathrm{O}\right): \delta=1.13\left(\mathrm{~d}, 3 \mathrm{H},{ }^{3} \mathrm{~J}_{\mathrm{H}, \mathrm{H}}=6.8 \mathrm{~Hz}, \mathrm{CHCH}_{3}\right), 1.21$ $\left(\mathrm{t}, 3 \mathrm{H},{ }^{3} \mathrm{~J}_{\mathrm{H}, \mathrm{H}}=6.9 \mathrm{~Hz}\right.$, butyl $\left.\mathrm{CH}_{3}\right), 1.29\left(\mathrm{~d}, 3 \mathrm{H},{ }^{3} J_{\mathrm{H}, \mathrm{H}}=6.8 \mathrm{~Hz}\right.$, $\left.\mathrm{CHCH}_{3}\right)$, 1.61-2.10 (m, 4H, butyl $\left.\mathrm{CH}_{2}\right), 2.08(\mathrm{~s}, 12 \mathrm{H}$, $\left.\mathrm{CH}_{3} \mathrm{COOK}\right) 2.24$ (s, 1H, cym- $\left.\mathrm{CH}_{3}\right), 2.52-2.72\left(\mathrm{~m}, 1 \mathrm{H}, \mathrm{CHMe}_{2}\right.$ ), 2.95-3.20 (m, 2H, butyl $\mathrm{CH}_{2}$ ), 3.47-3.60 (m, 1H, glucosyl $\mathrm{CH}$ ), 3.60-3.76 (m, 2H, glucosyl $\mathrm{CH}), 3.76-4.03(\mathrm{~m}, 2 \mathrm{H}$, glucosyl $\mathrm{CH}), 4.15\left(\mathrm{~d}, 1 \mathrm{H}, J=10.7 \mathrm{~Hz}\right.$, glucosyl $\left.\mathrm{C}^{6} \mathrm{H}\right), 4.35(\mathrm{~s}, 3 \mathrm{H}$, $\mathrm{NCH}_{3}$ ), 5.04-5.13 (m, 1H, $\left.\mathrm{C}_{\text {cym }} \mathrm{H}\right), 5.23(\mathrm{~d}, 1 \mathrm{HJ}=8.2 \mathrm{~Hz}$, glucosyl $\left.\mathrm{C}^{1} \mathrm{H}\right), 5.45\left(\mathrm{~d}, 1 \mathrm{H},{ }^{3} J_{\mathrm{H}, \mathrm{H}}=6.1 \mathrm{~Hz}, \mathrm{C}_{\text {cym }} \mathrm{H}\right), 5.77(\mathrm{~d}, 1 \mathrm{H}$, $\left.{ }^{3} J_{\mathrm{H}, \mathrm{H}}=5.7 \mathrm{~Hz}, \mathrm{C}_{\mathrm{cym}} \mathrm{H}\right), 5.82\left(\mathrm{~d}, 1 \mathrm{H},{ }^{3} J_{\mathrm{H}, \mathrm{H}}=5.7 \mathrm{~Hz}, \mathrm{C}_{\mathrm{cym}} \mathrm{H}\right)$.

\section{General procedure for transfer hydrogenation catalysis}

The Ru complex $(0.01 \mathrm{mmol})$ was dissolved in $\mathrm{iPrOH}(5 \mathrm{~mL})$ and aqueous $\mathrm{KOH}$ was added ( $2 \mathrm{M}, 0.05 \mathrm{~mL}, 0.10 \mathrm{mmol}$ ). Hexamethylbenzene was added as an internal standard. The solution was heated to reflux for $20 \mathrm{~min}$, then the ketone (1.00 mmol) was added and stirring at reflux was continued. Aliquots of the reaction mixture were sampled at given times and analyzed by diluting into $\mathrm{CDCl}_{3}$ and measuring ${ }^{1} \mathrm{H} \mathrm{NMR}$ spectra to monitor reaction progress.

\section{Conflicts of interest}

There are no conflicts to declare.

\section{Funding sources}

We acknowledge generous support from the European Commission for a Marie Skłodowska Curie Individual Fellowship to J. P. B. (Grant 749549) and from the European Research Council (CoG 615653), as well as the Swiss-European Mobility Programme for a visiting fellowship for P. M. to Bern. 


\section{References}

1 M. Melaimi, M. Soleilhavoup and G. Bertrand, Angew. Chem., Int. Ed., 2010, 49, 8810-8849.

2 L. Mercs and M. Albrecht, Chem. Soc. Rev., 2010, 39, 1903.

3 V. Dragutan, I. Dragutan, L. Delaude and A. Demonceau, Coord. Chem. Rev., 2007, 251, 765-794.

4 B. Alcaide, P. Almendros and A. Luna, Chem. Rev., 2009, 109, 3817-3858.

5 L. Schwartsburd and M. K. Whittlesey, in N-Heterocyclic Carbenes: Effective Tools for Organometallic Synthesis, ed. S. P. Nolan, Wiley-VCH, 2014, pp. 341-370.

6 L. Delaude and A. Demonceau, in N-Heterocyclic Carbenes: From Laboratory Curiosities to Efficient Synthetic Tools, ed. S. Diez-Gonzalez, Royal Society of Chemistry, 2nd edn, 2017, pp. 268-301.

7 B. K. Keitz, J. Bouffard, G. Bertrand and R. H. Grubbs, J. Am. Chem. Soc., 2011, 133, 8498-8501.

8 B. K. Keitz and R. H. Grubbs, Organometallics, 2010, 29, 403-408.

9 O. M. Ogba, N. C. Warner, D. J. O'Leary and R. H. Grubbs, Chem. Soc. Rev., 2018, 47, 4510-4544.

10 D. A. Hey, R. M. Reich, W. Baratta and F. E. Kühn, Coord. Chem. Rev., 2018, 374, 114-132.

11 M. Poyatos, J. A. Mata, E. Falomir, R. H. Crabtree and E. Peris, Organometallics, 2003, 22, 1110-1114.

12 W. Baratta, J. Schütz, E. Herdtweck, W. A. Herrmann and P. Rigo, J. Organomet. Chem., 2005, 690, 5570-5575.

13 R. Pretorius, Z. Mazloomi and M. Albrecht, J. Organomet. Chem., 2017, 845, 196-205.

14 M. Delgado-Rebollo, D. Canseco-Gonzalez, M. Hollering, H. Mueller-Bunz and M. Albrecht, Dalton Trans., 2014, 43, 4462-4473.

15 S. Enthaler, R. Jackstell, B. Hagemann, K. Junge, G. Erre and M. Beller, J. Organomet. Chem., 2006, 691, 4652-4659.

16 W. W. N. O, A. J. Lough and R. H. Morris, Organometallics, 2009, 28, 6755-6761.

17 X.-Q. Guo, Y.-N. Wang, D. Wang, L.-H. Cai, Z.-X. Chen and X.-F. Hou, Dalton Trans., 2012, 41, 14557.

18 M. Hollering, M. Albrecht and F. E. Kühn, Organometallics, 2016, 35, 2980-2986.

19 A. Prades, E. Peris and M. Albrecht, Organometallics, 2011, 30, 1162-1167.

20 A. Bolje, S. Hohloch, D. Urankar, A. Pevec, M. Gazvoda, B. Sarkar and J. Košmrlj, Organometallics, 2014, 33, 2588-2598.

21 B. Bagh, A. M. McKinty, A. J. Lough and D. W. Stephan, Dalton Trans., 2014, 43, 12842-12850.

22 R. Pretorius, J. Olguín and M. Albrecht, Inorg. Chem., 2017, 56, 12410-12420.

23 S. Hohloch, L. Hettmanczyk and B. Sarkar, Eur. J. Inorg. Chem., 2014, 2014, 3164-3171.

24 L. Bernet, R. Lalrempuia, W. Ghattas, H. Mueller-Bunz, L. Vigara, A. Llobet and M. Albrecht, Chem. Commun., 2011, 47, 8058.

25 P. Mathew, A. Neels and M. Albrecht, J. Am. Chem. Soc., 2008, 130, 13534-13535.
26 K. F. Donnelly, A. Petronilho and M. Albrecht, Chem. Commun., 2013, 49, 1145-1159.

27 Á. Vivancos, C. Segarra and M. Albrecht, Chem. Rev., 2018, 118, 9493-9586.

28 V. V. Rostovtsev, L. G. Green, V. V. Fokin and K. B. Sharpless, Angew. Chem., 2002, 114, 27082711.

29 C. W. Tornøe, C. Christensen and M. Meldal, J. Org. Chem., 2002, 67, 3057-3064.

30 W. H. Binder and R. Sachsenhofer, Macromol. Rapid Commun., 2007, 28, 15-54.

31 J. A. Johnson, M. G. Finn, J. T. Koberstein and N. J. Turro, Macromol. Rapid Commun., 2008, 29, 1052-1072.

32 P. L. Golas and K. Matyjaszewski, Chem. Soc. Rev., 2010, 39, 1338-1354.

33 H. C. Kolb and K. B. Sharpless, Drug Discovery Today, 2003, 8, 1128-1137.

34 J. D. Crowley and P. H. Bandeen, Dalton Trans., 2010, 39, 612-623.

35 J. D. Crowley, S. M. Goldup, A.-L. Lee, D. A. Leigh and R. T. McBurney, Chem. Soc. Rev., 2009, 38, 1530.

36 J. P. Byrne, S. Blasco, A. B. Aletti, G. Hessman and T. Gunnlaugsson, Angew. Chem., Int. Ed., 2016, 55, 89388943.

37 J. P. Byrne, J. A. Kitchen, J. E. O’Brien, R. D. Peacock and T. Gunnlaugsson, Inorg. Chem., 2015, 54, 14261439.

38 J. M. Holub and K. Kirshenbaum, Chem. Soc. Rev., 2010, 39, 1325.

39 X. Liu, R. B. P. Elmes and K. A. Jolliffe, Aust. J. Chem., 2017, 70, 201.

40 V. K. Tiwari, B. B. Mishra, K. B. Mishra, N. Mishra, A. S. Singh and X. Chen, Chem. Rev., 2016, 116, 30863240 .

41 C. Bouillon, A. Meyer, S. Vidal, A. Jochum, Y. Chevolot, J. P. Cloarec, J. P. Praly, J. J. Vasseur and F. Morvan, J. Org. Chem., 2006, 71, 4700-4702.

42 M. Milne, K. Chicas, A. Li, R. Bartha and R. H. E. Hudson, Org. Biomol. Chem., 2012, 10, 287-292.

43 S. Horn, C. Gandolfi and M. Albrecht, Eur. J. Inorg. Chem., 2011, 2011, 2863-2868.

44 A. Monney, G. Venkatachalam and M. Albrecht, Dalton Trans., 2011, 40, 2716.

45 J. D. Crowley, A.-L. Lee and K. J. Kilpin, Aust. J. Chem., 2011, 64, 1118-1132.

46 R. Noyori and S. Hashiguchi, Acc. Chem. Res., 1997, 30, 97102.

47 R. Noyori, M. Yamakawa and S. Hashiguchi, J. Org. Chem., 2001, 66, 7931-7944.

48 T. Ohkuma, N. Utsumi, K. Tsutsumi, K. Murata, C. Sandoval and R. Noyori, J. Am. Chem. Soc., 2006, 128, 8724-8725.

49 Y. Shvo, D. Czarkie, Y. Rahamim and D. F. Chodosh, J. Am. Chem. Soc., 1986, 108, 7400-7402.

50 B. L. Conley, M. K. Pennington-Boggio, E. Boz and T. J. Williams, Chem. Rev., 2010, 110, 2294-2312. 
51 W. W. N. O, A. J. Lough and R. H. Morris, Chem. Commun., 2010, 46, 8240.

52 W. B. Cross, C. G. Daly, Y. Boutadla and K. Singh, Dalton Trans., 2011, 40, 9722.

53 A. Bartoszewicz, R. Marcos, S. Sahoo, A. K. Inge, X. Zou and B. Martín-Matute, Chem. - Eur. J., 2012, 18, 1451014519.

54 A. Bartoszewicz, G. González Miera, R. Marcos, P. O. Norrby and B. Martín-Matute, ACS Catal., 2015, 5, 37043716.

55 G. González Miera, E. Martínez-Castro and B. MartínMatute, Organometallics, 2018, 37, 636-644.

56 S. Woodward, M. Diéguez and O. Pàmies, Coord. Chem. Rev., 2010, 254, 2007-2030.

57 S. Castillón, C. Claver and Y. Díaz, Chem. Soc. Rev., 2005, 34, 702 .

58 A. S. Henderson, J. F. Bower and M. C. Galan, Org. Biomol. Chem., 2016, 14, 4008-4017.

59 W. Zhao, V. Ferro and M. V. Baker, Coord. Chem. Rev., 2017, 339, 1-16.

60 K. J. Kilpin, S. Crot, T. Riedel, J. A. Kitchen and P. J. Dyson, Dalton Trans., 2014, 43, 1443-1448.

61 K. Purkait, S. Karmakar, S. Bhattacharyya, S. Chatterjee, S. K. Dey and A. Mukherjee, Dalton Trans., 2015, 44, 59695973.

62 A. S. Henderson, J. F. Bower and M. C. Galan, Org. Biomol. Chem., 2014, 12, 9180-9183.

63 H. Paulsen, Z. Györgydeák and M. Friedmann, Chem. Ber., 1974, 107, 1568-1578.
64 P. Quagliotto, G. Viscardi, C. Barolo, D. D’Angelo, E. Barni, C. Compari, E. Duce and E. Fisicaro, J. Org. Chem., 2005, 70, 9857-9866.

65 S. M. Paterson, J. Clark, K. A. Stubbs, T. V. Chirila and M. V. Baker, J. Polym. Sci., Part A: Polym. Chem., 2011, 49, 4312-4315.

66 H. M. J. Wang and I. J. B. Lin, Organometallics, 1998, 17, 972-975.

67 D. Canseco-Gonzalez and M. Albrecht, Dalton Trans., 2013, 42, 7424.

68 C. C. Yang, P. S. Lin, F. C. Liu, I. J. B. Lin, G. H. Lee and S. M. Peng, Organometallics, 2010, 29, 5959-5971.

69 Y. Imanaka, H. Hashimoto, I. Kinoshita and T. Nishioka, Chem. Lett., 2014, 43, 687-689.

70 B. Ren, M. Wang, J. Liu, J. Ge, X. Zhang and H. Dong, Green Chem., 2015, 17, 1390-1394.

71 J. J. Topczewski, P. J. Cabrera, N. I. Saper and M. S. Sanford, Nature, 2016, 531, 220-224.

72 M. T. Reetz and T. Neugebauer, Angew. Chem., Int. Ed., 1999, 38, 179-181.

73 M. Guitet, P. Zhang, F. Marcelo, C. Tugny, J. JiménezBarbero, O. Buriez, C. Amatore, V. Mouriès-Mansuy, J. P. Goddard, L. Fensterbank, Y. Zhang, S. Roland, M. Ménand and M. Sollogoub, Angew. Chem., Int. Ed., 2013, 52, 7213-7218.

74 J. F. Moya, C. Rosales, I. Fernández and N. Khiar, Org. Biomol. Chem., 2017, 15, 5772-5780.

75 M. Coll, O. Pàmies and M. Diéguez, Adv. Synth. Catal., 2014, 356, 2293-2302. 